\title{
Nine Lives: The Punitive Damage Class
}

\author{
Linda S. Mullenix*
}

In essence, rather than portend the death of the punitive damage class action, the recent Supreme Court jurisprudence creates powerful new arguments in favor of the aggregate model of punitive damage adjudication that offers a route back towards the viable use of class actions in mass tort scenarios. ${ }^{1}$

The work begins anew. The hope rises again. And the dream lives on. ${ }^{2}$

\section{INTRODUCTION}

The concept of the punitive damage class has a long and dubious lineage, extending back more than thirty years. ${ }^{3}$ During the 1980 s and, especially, the 1990s the concept of the punitive damage class excited plaintiffs' attorneys, ${ }^{4}$ inspired countless academics, ${ }^{5}$ riveted at least a few

* $\quad$ Morris \& Rita Atlas Chair in Advocacy, University of Texas School of Law.

1. James M. Underwood, Road to Nowhere or Jurisprudential U-Turn? The Intersection of Punitive Damage Class Actions and the Due Process Clause, 66 WASH. \& LEE L. REV. 763, 763 (2009).

2. Senator Edward Kennedy, Remarks at the Democratic National Convention, (August 25, 2008) (transcript available at http://elections.nytimes.com/2008/president/conventions/videos /transcripts/20080825_KENNEDY_SPEECH.html).

3. See e.g., Payton v. Abbott Labs., 83 F.R.D. 382, 389 (D. Mass. 1979) (disapproving proposed Rule 23(b)(1)(B) punitive damage class) vacated, 100 F.F.D. 336 (D. Mass. 1983) (vacating Rule 23(b)(3) class); Abed v. A.H. Robins Co. (In re N. Dist. of Cal., Dalkon Shield IUD Prods. Liab. Litig.), 693 F.2d 847 (9th Cir. 1982) [hereinafter Dalkon Shield].

4. See e.g., Elizabeth Cabraser, Unfinished Business: Reaching the Due Process Limits of Punitive Damages in Tobacco Litigation Through Unitary Classwide Adjudication, 36 WAKE FOREST L. REV. 979, 982 (2001) ("The use of the class mechanism to determine and distribute punitive damages brings rationality and proportionality to the process and achieves more equitable and socially palatable results."); Elizabeth J. Cabraser \& Robert J. Nelson, Class Action Treatment of Punitive Damage Issues After Philip Morris v. Williams: We Can Get There from Here, 2 Charleston L. REV. 407, 430 (2008) (urging that the Class Action Fairness Act of 2005 presents "an intriguing format for cost-effective determination of punitive damages liability and quantum to large numbers of plaintiffs in a single proceeding"); Elizabeth J. Cabraser \& Thomas M. Sobol, Equity for the Victims, Equity for the Transgressor: The Classwide Treatment of Punitive Damages Claims, 74 TUl. L. REV. 2005, 2006 (2000); Thomas M. Sobol \& Elizabeth J. Cabraser, Complex Litigation: Punitive Damages Class II, NAT'L L.J., March 6, 2000, at A17 (“At least in the mass tort context, therefore, in which the number of claimants is large, the pool of available punitive damage 
defense counsel, ${ }^{6}$ and caught the attention of a scattering of federal judges. ${ }^{7}$ Nonetheless, certification of actual punitive damage classes has proved elusive, as court after court refused to give their imprimatur to the punitive damage class. ${ }^{8}$ In truth, the history of the punitive damage class has been one of repeated repudiation, punctuated by scattered, anomalous success (a point which its advocates have difficulty acknowledging). ${ }^{9}$

dollars may be a classic 'limited fund' warranting 'limited punishment' through 23(b)(1)(B) certification for a single punitive damages trial, or a comprehensive settlement of punitive damages liability.").

5. There is a sizeable literature on punitive damages and class litigation that was generated during the 1980s and 1990s. See generally Margaret Meriwether Cordray, The Limits of State Sovereignty and the Issue of Multiple Punitive Damages Awards, 78 OR. L. REV. 275 (1999); Kevin M. Forde, Punitive Damages in Mass Tort Cases: Recovery on Behalf of a Class, 15 LOY. U. CHI. L.J. 397 (1984); Marc Galanter \& David Luban, Poetic Justice: Punitive Damages and Legal Pluralism, 42 AM. U. L. REV. 1393 (1993); Keith N. Hylton, Punitive Damages and the Economic Theory of Penalties, 87 GEO. L.J. 421 (1998); John Calvin Jeffries, Jr., A Comment on the Constitutionality of Punitive Damages, 72 VA. L. REV. 139 (1986); Dennis Neil Jones et al., Multiple Punitive Damages Awards for a Single Course of Wrongful Conduct: The Need for a National Policy to Protect Due Process, 43 ALA. L. ReV. 1 (1991); David G. Owen, Problems in Assessing Punitive Damages Against Manufacturers of Defective Products, 49 U. CHI. L. ReV. 1 (1982); Mark Donald Peters, Comment, Punitive Damages, the Common Question Class Action, and the Concept of Overkill, 13 PAC. L.J. 1273 (1982); A. Mitchell Polinsky \& Steven Shavell, Punitive Damages: An Economic Analysis, 111 HARV. L. REv. 869 (1998); Gary T. Schwartz, Mass Torts and Punitive Damages: A Comment, 39 VILL. L. Rev. 415 (1994); Richard A. Seltzer, Punitive Damages in Mass Tort Litigation: Addressing the Problems of Fairness, Efficiency and Control, 52 ForDHAM L. REV. 37 (1983); Cass R. Sunstein et al., Assessing Punitive Damages (with Notes on Cognition and Valuation in Law), 107 YALE L.J. 2071 (1998); Malcolm E. Wheeler, The Constitutional Case for Reforming Punitive Damages Procedures, 69 VA. L. REV. 269 (1983).

6. See e.g., Victor E. Schwartz et al., Reigning in Punitive Damages "Run Wild": Proposals for Reform by Courts and Legislatures, 65 BROOK. L. REV. 1003 (1999).

7. See e.g., In re "Agent Orange" Prods. Liab. Litig., 100 F.R.D. 718, 728 (E.D.N.Y. 1983) (Judge Jack B. Weinstein certifying Rule 23(b)(1)(B) punitive damage class in Agent Orange litigation); Jack B. Weinstein \& Eileen B. Hershenov, The Effect of Equity on Mass Tort Law, 1991 U. ILL. L. REV. 269, 290 (1991) ("No matter how financially healthy [mass tort defendants may be], the sheer number of present and future victims means that we are ultimately dealing with a limited compensation fund.").

8. See e.g., In re School Asbestos Litig., 789 F.2d 996, 1005-06 (3d Cir. 1986); In re Bendectin Prods. Liab. Litig., 749 F.2d 300, 306 (6th Cir. 1984); In re Federal Skywalk Cases, 680 F.2d 1175, 1184 (8th Cir. 1982); Dalkon Shield, supra note 3, 693 F.2d at 852; In re Rail Collision Near Chase, Md., on Jan. 4, 1987 Litig., 9 Fed. R. Serv. 3d (West) 1045 (D. Md. Dec. 8, 1987); Payton, 83 F.R.D. at 389.

9. See e.g., In re Exxon Valdez, 26 F.3d 130 (9th Cir. 1994) (unpublished table decision) (dismissing challenge to Rule 23(b)(1)(B) punitive damage class certification as not appealable; In re Diamond Shamrock Chems. Co., 725 F.2d 858, 862 (2d Cir. 1984) (refusing to decertify the Rule 23(b)(1)(B) punitive damage class certified in the Agent Orange litigation); Agent Orange, 100 F.R.D. at 718; In re Shell Oil Refinery, 136 F.R.D. 588, 591 (E.D. La. 1991), aff'd sub nom., Watson v. Shell Oil Co., 979 F.2d 1014 (5th Cir. 1992); cf. Cimino v. Raymark Indus., 751 F. Supp. 649, 657-58 (E.D. Tex. 1990) (approving trial plan for determining classwide liability for punitive damages, with individual award determinations in subsequent trial phases), aff'd in part, rev'd in part, 151 F.3d 297 (5th Cir. 1998). 
The punitive damage class's Waterloo, however, clearly arrived with the Supreme Court's decision in Ortiz v. Fibreboard Corp. ${ }^{10}$ celebrated, or at least commemorated in this symposium. Because the Rule 23(b)(1)(B) limited-fund class category has been the usual procedural vehicle for the punitive damage class, ${ }^{11}$ the Court's exacting requirements for certification of a limited-fund class action in Ortiz foredoomed almost every subsequent attempt to certify a punitive damage class.

And yet, as we shall see, the punitive damage class has proved enduring and hard to stave off. Hence, the Supreme Court's string of punitive damage cases, ${ }^{12}$ decided in the 1990 s and into the twenty-first century, breathed new life into the moribund idea of the punitive damage class. The Court's suggestions of constitutional constraints on punitive damage awards provided a basis for advancing the argument for the Rule 23(b)(1)(B) limited fund. Seizing this jurisprudence, Judge Jack Weinstein cobbled together an innovative theory to undergird certification of a punitive damage class in In re Simon II Litigation, ${ }^{13}$ thus providing renewed hope to the advocates of the punitive damage class. ${ }^{14}$ Nevertheless, in 2005-more than twenty-five years after the first suggestion of a punitive damage class - the Second Circuit unceremoniously buried the punitive damage class once again. ${ }^{15}$

10. 527 U.S. 815 (1999).

11. See Cabraser \& Nelson, supra note 4, at 422 ("Class actions focusing on punitive damages claims have most frequently sought certification under Fed. R. Civ. P. 23(b)(1)(B), commonly known as the 'limited fund' provision."). Some punitive damage classes have been sought and certified pursuant to Rule 23(b)(3), but these examples are somewhat anomalous. See infra Part II.B.1. Even fewer punitive damage classes have been pursued under Rule 23(b)(2), the class category for injunctive and declaratory relief. See infra Part II.B.3.

12. See State Farm Mut. Auto. Ins. Co. v. Campbell, 538 U.S. 408 (2003); Cooper Indus. v. Leatherman Tool Group, 532 U.S. 424 (2001); BMW of North America v. Gore, 517 U.S. 559 (1996); TXO Prod. Corp. v. Alliance Res., 509 U.S. 443 (1993); Pac. Mut. Life Ins. Co. v. Haslip, 499 U.S. 1 (1991).

13. 211 F.R.D. 86, $163-65$ (E.D.N.Y. 2002), vacated, 407 F.3d 125 (2d Cir. 2005).

14. There has been a revival of interest in the punitive damage class since the Court decided Ortiz. See, e.g., Cabraser, supra note 4; Cabraser \& Nelson, supra note 4; Jeffrey L. Fisher, The Exxon Valdez Case and Regularizing Punishment, 26 AlASKA L. REV. 1 (2009); Laura J. Hines, Obstacles to Determining Punitive Damages in Class Actions, 36 WAKe Forest L. ReV. 889 (2001); Semra Mesulam, Note, Collective Rewards and Limited Punishment: Solving the Punitive Damages Dilemma with Class, 104 Colum. L. Rev. 1114 (2004); Richard A. Nagareda, Punitive Damage Class Actions and the Baseline of Tort, 36 WAKE FOREST L. REV. 943 (2001); Aileen L. Nagy, Note, Certifying Mandatory Punitive Damages Classes in a Post-Ortiz and State Farm World, 58 VAND. L. REV. 599 (2005); Joan Steinman, Managing Punitive Damages: A Role for Mandatory "Limited Generosity" Classes and Anti-Suit Injunctions?, 36 WAKE FOREST L. REV. 1043 (2001); Symposium, Engle v. R.J. Reynolds Tobacco Co.: Lessons in State Class Actions, Punitive Damages, and Jury Decision-Making, 36 WAKE FOREST L. REV. 871 (2001); Underwood, supra note 1 .

15. In re Simon II Litig. 407 F.3d 125, 136-40 (2d Cir. 2005). The Second Circuit did 
One would think that the combined Ortiz and Simon II decisions definitively would have interred the punitive damage class forever. But this has turned out not to be entirely true. In July 2006, the Fifth Circuit upheld class certification of a Rule 23(b)(1)(B) punitive damage settlement class, brought on behalf of individuals who took out loans and bought insurance from Washington Mutual Finance Group in Mississippi. ${ }^{16}$ Applying an Ortiz-like analysis in a scant three-page decision, the Fifth Circuit concluded that the district court had not abused its discretion in finding that a limited fund existed to support certification of a punitive damage class. ${ }^{17}$ Notably, the Fifth Circuit's decision was not selected for publication in the Federal Reporter, and therefore enjoys questionable precedential authority.

Since that Fifth Circuit unpublished decision, it is difficult to find a single reported decision where a federal court has certified a Rule 23(b)(1)(B) limited-fund punitive damage class. ${ }^{18}$ Nonetheless, in the groves of academe and among plaintiffs' counsel, the punitive damage

acknowledge, however, its prior approval, in the Agent Orange litigation, of a Rule 23(b)(1)(B) punitive damage class. Id. at 132 n.5. However, other commentators have interpreted the Court's series of punitive damages cases to "spell the death knell for the punitive damage class action." E.g., Underwood, supra note 1, at 779 .

16. Baker v. Washington Mut. Fin. Group, 193 F. App'x 294, 298 (5th Cir. 2006).

17. Id. at 297. This action involved a settlement class, rather than a litigation class. The settlement did not provide for injunctive or declaratory relief. Rather, the settlement established a \$7 million fund for class members who filed claims forms. The agreement designated $\$ 3.5$ million for compensatory damages and $\$ 3.5$ million for punitive damages. The settlement, certified by the district court under Rule 23(b)(1)(B), permitted class members to opt out of the compensatory portion of the settlement, but did not permit class members to opt out of the punitive damage portion of the agreement. The district court relied on the Supreme Court's punitive damage decisions, construing a constitutional limit on aggregate punitive damages. Id. The settlement was challenged by intervenors, who argued that the settlement did not satisfy the requirements of Ortiz. The intervenors contended that the $\$ 3.5$ million punitive damage number must have been "plucked out of thin air." Id. at 298. In upholding the certification, the Fifth Circuit disagreed, but did not rely on the line of punitive damage decisions setting forth constitutional constraints of such awards. The Fifth Circuit concluded:

The district court accepted both of [the defendant's] arguments and held that a limited fund existed both legally and factually. We need not address the district court's legal finding that substantive due process and its ban on excessive punitive damages can create a limited fund because the district court's factual finding that a limited fund existed was not an abuse of discretion.

Id. at 297. Notably, the Fifth Circuit made no reference to the Second Circuit's decision in Simon II, most likely because the Fifth Circuit eschewed reliance on the Supreme Court's constitutional punitive damage decisions to hold that the settlement satisfied Ortiz's requirements for a limitedfund punitive damage class.

18. This is not to suggest that such classes have not been certified. Instead, analysis of class certification issues has always been complicated by the fact that reported decisions may not reflect the true universe of judicial orders, or may present a distorted portrait of actual practice. Moreover, with regard to punitive damage class certification, analysts and commentators are compelled to make arguments from very small samples of reported decisions. 
class seems to enjoy the feline attribute of multiple lives. Hence, one academic commentator recently authored a strenuous defense of the punitive damage class that, he claims, "offers a route back towards the viable use of class actions in mass tort scenarios." 19 In addition, distinguished plaintiffs' mass-tort attorneys (and tireless advocates for the punitive damage class) have suggested revitalized support for the punitive damage class pursuant to the Class Action Fairness Act of 2005 (CAFA). ${ }^{20}$

For those who have lived through thirty years of mass-tort litigation, this renewed advocacy on behalf of the punitive damage class presents a rather intriguing, if not preposterous, prospect. The renewed arguments in favor of the punitive damage class take three forms. First, it is urged that courts take an expansive view of the Supreme Court's holdings in both Ortiz and Phillip Morris USA v. Williams, ${ }^{21}$ and interpret such decisions to support certification of punitive classes under Rule 23(b)(3). ${ }^{22}$ Second, other commentators suggest that the Supreme Court ought to grant review of a certified 23(b)(1)(B) punitive damage class, in order to create a specific exception to Ortiz that would authorize courts to certify punitive damage classes under $23(\mathrm{~b})(1)(\mathrm{B}) .^{23}$ Third, plaintiffs'

19. Underwood, supra note 1, at 764. Resuscitating the punitive damage class also seems to be a favorite subject among law-school students. A Columbia University law student has attempted to revive the punitive damage class by suggesting how the Supreme Court could reconcile its decisions in both Ortiz and Campbell. See Nagy, supra note 14, at 629 ("Fairness to both plaintiffs and defendants, combined with the desire for efficiency in the resolution of mass tort cases, suggests a need for change. Unconstrained by explicit language in Ortiz that prohibits certification of mandatory punitive damage classes, the Supreme Court is in a position to carve out an exception from the traditional application of 23(b)(1)(B) for punitive damage classes, allowing certification to accommodate the interests of defendants and plaintiffs alike."). In her Note, Ms. Nagy draws most of her authoritative support for her analysis and conclusions from the writings of Elizabeth Cabraser, a prominent plaintiffs' attorney and longstanding advocate for court certification of punitive damage classes.

Another Columbia Law School student similarly has urged the marriage of the Supreme Court's punitive damage jurisprudence to the Rule 23(b)(1)(B) punitive damage class:

The debate over the punitive damage class could not be more important, or more timely.

At a moment when corporations wield the sort of social power previously considered the exclusive province of government, the need for clarification on the punitive damages case law is becoming ever more pressing. The punitive damages class action is a unique tool enabling individuals and communities to negotiate their relationships with private entities. This procedural mechanism has the potential to alter radically the landscape of mass tort litigation.

Mesulam, supra note 14, at 1118 (citations omitted).

20. Cabraser \& Nelson, supra note 4 , at 430.

21. 127 S. Ct. 1057, 1063 (2007) (stating that in a non class action setting, the Due Process Clause of the Constitution prohibits juries from basing a punitive damage award on a desire to punish a defendant for injuries inflicted upon non parties to the dispute).

22. Underwood, supra note 1, at 796-807. See also infra Part IV.B.

23. Nagy, supra note 14, at 624-29. See also infra Part IV.A. 
attorneys argue that CAFA opens the door to creative use of the punitive damage class through the law's authorization for "mass-action" cases. ${ }^{24}$

This Article examines these theories currently urged in support of the punitive damage class and assesses whether there actually is a viable means of sustaining a punitive damage class in the post-Ortiz, postSimon II class action era. The Article concludes that prevailing class action jurisprudence, integrated with the Court's punitive damage jurisprudence, is unlikely to support certification of a Rule 23(b)(3) punitive damage class. In addition, the Supreme Court is extremely unlikely to create an Ortiz exception for punitive damage classes. Finally, the article suggests that CAFA cannot and does not support any Congressional intent to approve punitive damage classes as "mass actions" under this new jurisdictional statutory scheme.

\section{THIRTY YeARS OF THE PUNITIVE DAMAGE Class CONCEPT: A VERY SHORT HISTORY}

\section{A. Early Ventures in the Punitive Damage Class}

The history of the punitive damage class is worth at least some cursory review, if for no other reason than to note the scarcity of the record and the thinness of doctrinal analysis. The history of the punitive damage class centers on a small cluster of reported decisions that are largely devoid of a meaningful jurisprudence. Nonetheless, the concept of the punitive damage class has managed to seize the imaginations of numerous academics and the plaintiffs' bar. As will be seen, advocates on both sides of the debate have constructed elaborate arguments based on slim and insubstantial precedent.

The concept of the punitive damage class was first forged in the heyday of mass-tort litigation, during the 1980s and 1990s when federal courts were inundated with massive tort and products-liability litigation. This era marked a "mass-tort litigation" crisis in federal and state courts, when parties and the judiciary were uncertain how to adjudicate massive, complex tort litigation and, therefore, were engaged in substantial innovative, experimental efforts to resolve the litigation crisis. Among many proposed novel techniques for resolving mass torts, the punitive damage class emerged as a potential vehicle for resolving aggregate punitive liability on a classwide basis. 
Nonetheless, the concept of a punitive damage class was a novel idea. As such, the punitive damage class presented challenges for the pleader and for the courts: how should a plaintiff seek class certification of a punitive damage class under Rule 23, and what was required for valid class certification? We may surmise that plaintiffs' attorneys were uncertain how to proceed because the cases during this period reflect that some counsel sought certification under Rule 23(b)(3)-the damage optout class-while others sought class certification under $23(\mathrm{~b})(1)(\mathrm{B}){ }^{25}$ We may further deduce that the punitive damage class was something of a litigation novelty because plaintiffs' attorneys frequently made little effort (or certainly insufficient effort) to provide the court with an evidentiary record in support of certification of the punitive damage class. $^{26}$

One need not dwell very long on the judicial reception to the punitive damage class prior to Ortiz because there are scant decisions relating to class certification pursuant to Rule 23(b)(1)(B) and even fewer focusing on certification of a punitive damage class. Moreover, in the few instances where plaintiffs sought certification of a 23(b)(1)(B) punitive damage class, courts rarely provided an extensive discussion of their rationales for denying or granting certification. Hence, prior to Ortiz, it is perhaps fair to suggest that there was no considered jurisprudence relating to the 23(b)(1)(B) class generally or to the punitive damage class specifically. ${ }^{27}$ Rather, the reported decisions comprised a hodge-podge collection of cursory review by scattered courts.

25. See In re Exxon Valdez, 26 F.3d 130 (9th Cir. 1994) (unpublished table decision) (noting that the district court certified a mandatory class pursuant to Rule 23(b)(1)(B)); Sterling v. Velsicol Chemical Corp., 855 F.2d 1188, 1196-97 (6th Cir. 1988) (affirming classwide treatment of compensatory and punitive damage claims in landfill contamination action under 23(b)(3); compensatory damage claims tried first, followed by classwide punitive damages); In re "Agent Orange" Prod. Liab. Litig., 100 F.R.D. 718, 721-25 (E.D.N.Y. 1983) (noting that plaintiffs sought certification of a class under Rules 23(b)(1)(A) and 23(b)(3), and mandatory class certification pursuant to 23(b)(1)(B)). But see In re Copley Pharmaceutical Inc., "Albuterol" Prods. Liab. Litig., 161 F.R.D. 456, 467-68 (D. Wyo. 1995) (finding certification of a punitive damage class under Rule 23(b)(3) inappropriate because punitive damages must relate to particular plaintiff).

26. During the first decade of mass-tort litigation, plaintiffs' attorneys tended a scattershot approach to class certification, seeking certification under all provisions of Rule 23(b)(1)(A), (b)(1)(B), (b)(2), and (b)(3). Because the law was unsettled, there seemed to be a sense that class counsel should plead everything to see what would stick with the courts. In this spirit, the era's thin pleadings on Rule 23 punitive damage classes reflect both uncertainty in the law as well as a halfhearted cover-all-bases approach to pleading.

27. Prior to Ortiz, the most extensive attempt to articulate some jurisprudential basis for a punitive damage class may be found in the Third Circuit's decision In re School Asbestos Litigation, 789 F.2d 996, 1003-08 (3d Cir. 1986) (providing a lengthy discussion of purpose of punitive damages and possible rationales for certifying a punitive damage class). 
With a few limited exceptions noted below, plaintiffs' attempts to certify punitive damage classes prior to Ortiz were largely unsuccessful. Courts routinely rejected proposed Rule 23(b)(1)(B) damage classes for at least five reasons: (1) insufficient proof of a limited fund, (2) impermissible violation of the federal Anti-Injunction Act, (3) applicable law problems, (4) existence of an under-inclusive class, and (5) impermissible circumvention of the bankruptcy laws.

The most frequently cited reason for denial of a proposed Rule 23(b)(1)(B) punitive damage class was the failure of the proponents either to provide the court with any evidence of the limited fund, or the plaintiffs' failure in providing sufficient evidence of the limited fund. ${ }^{28}$ Prior to Ortiz, federal courts split concerning what standard of proof a proponent of a limited-fund class needed to satisfy in order for a court to certify such a class. ${ }^{29}$ Some courts held that the proponent of the limited fund needed to show that a limited fund would "necessarily" affect the other plaintiffs' claims. ${ }^{30}$ Other federal courts suggested that the proponents needed merely to show that there was a "substantial probability" that a limited fund would affect other class members' rights. $^{31}$

However, federal courts agreed that, irrespective of the proper test, a district court as a matter of law had to make a fact-finding inquiry on the question of the existence of a limited fund, and that the failure to do so constituted judicial error in certifying a class. ${ }^{32}$ Moreover, the party opposing class certification had to be afforded an opportunity to dispute whether there was a limited fund. ${ }^{33}$ Clearly, this prior debate concerning

28. See, e.g., In re Bendectin Prods. Liab. Litig., 749 F.2d 300, 306 (6th Cir. 1984) ("[T]he district court, as a matter of law, must have a fact-finding inquiry [on the issue of a limited fund] and allow opponents of class certification to present evidence that a limited fund does not exist. Because the district judge ... failed to make any such finding, the certification was clearly erroneous as a matter of law." (citations omitted)); Payton v. Abbott Labs., 83 F.R.D. 382, 389 (D. Mass. 1979) ("The plaintiffs do not, however, offer evidence of the likely insolvency of the defendants, and I do not believe that, without more, numerous plaintiffs and a large ad damnum clause should guarantee (b)(1)(B) certification."); cf. Sch. Asbestos Litig., 789 F.2d at 1003-05 (stating that plaintiffs presented no evidence that the defendants' available assets would be insufficient to pay all claims, but cautioning that "powerful arguments for preventing repeated awards of punitive damages for the same act or series of acts ... might provide a threshold justification for the exercise of discretion in certifying a nationwide (mandatory) Rule 23(b)(1)(B) class for punitive damages").

29. Bendectin, 749 F.2d at 306.

30. E.g., Dalkon Shield, supra note 3, 693 F.2d at 852 ("Rule 23(b)(1)(B) certification is proper only when separate punitive damage claims necessarily will affect later claims.”).

31. E.g., In re "Agent Orange", 100 F.R.D. at 726 ("[T] he proper standard is whether there is a substantial probability - that is less than a preponderance but more than a mere possibility- that if damages are awarded, the claims of earlier litigants would exhaust the defendants' assets.").

32. Bendectin, 749 F.2d at 306.

33. Id. 
the proper standard for finding a limited fund has now been superseded by the standards set forth in Ortiz, which set the bar for certification of a 23(b)(1)(B) punitive damage class. ${ }^{34}$

A second and somewhat anomalous rationale for rejecting certification of a Rule 23(b)(1)(B) punitive damage class was that such a mandatory class action order impermissibly violated the federal AntiInjunction Act by restraining state court claimants from settling their claims. $^{35}$ The Eighth Circuit announced this theory in the Federal Skywalk cases, where the Court suggested that a district court's order certifying a punitive damage class operated as an injunction against pending state proceedings, and therefore violated federal law prohibiting federal injunctions of pending parallel state-court proceedings. ${ }^{36}$ Although the Anti-Injunction Act rationale for rejecting 23(b)(1)(B) certification was invoked but not applied in the School Asbestos Litigation, ${ }^{37}$ the rationale largely failed to gain traction in federal jurisprudence. ${ }^{38}$

A third reason courts denied class certification to a proposed nationwide Rule 23(b)(1)(B) punitive damage class arises from differences in applicable law. Thus, early on, the Ninth Circuit in the Dalkon Shield litigation rejected a district court's certification of a nationwide punitive damage class where the court concluded that "the 50 jurisdictions in which these cases arise do not apply the same punitive

34. See Ortiz v. Fibreboard Corp., 527 U.S. 815, 838-40 (1999).

35. 28 U.S.C. $§ 2283$ (2006) (codifying the Anti-Injunction Act).

36. In re Federal Skywalk Cases, 680 F.2d 1175 (8th Cir. 1982). See Hines, supra note 14, at 906-07 (discussing rejection of 23(b)(1)(B) class based on Anti-Injunction Act).

37. In re Sch. Asbestos Litig., 789 F.2d 996 (3d Cir. 1986). The district court had conditionally certified a mandatory class under Rule 23(b)(1)(B), finding that there was a "substantial possibility that early awards of punitive damages in individual cases [would] impair or impede the ability of future claimants to obtain punitive damages." In re Asbestos Sch. Litig., 104 F.R.D. 422, 437 (E.D. $\mathrm{Pa}$. 1984). The defendants appealed this portion of the district court's class certification order on several grounds, including that the court's order violated the Anti-Injunction Act. The appellate court did not review the 23(b)(1)(B) order on the Anti-Injunction argument. 789 F.2d 996 (3d Cir. 1986).

38. But see In re Exxon Valdez, 26 F.3d 130 (9th Cir. 1994) (unpublished table decision) (commenting on the Federal Skywalk Anti-Injunction challenge to mandatory class certification, concluding that the Anti-Injunction Act rationale did not apply to the court's order, and ultimately dismissing appeal for lack of jurisdiction). The Federal Skywalk decision was largely criticized in academic commentary. See generally Richard P. Cusick, Procedural Impediments to the Resolution of Mass Tort Cases: The Anti-Injunction Act and the Due Process Clause, 12 OHIO ST. J. ON DISP. RESOL. 485 (1997); Robert C. Gordon, The Optimum Management of the Skywalks Mass Disaster Litigation by the Use of the Federal Mandatory Class Action Device, 52 UMKC L. REV. 215 (1984); Steven M. Larimore, Exploring the Interface Between Rule 23 Class Actions in the Anti-Injunction Act, 18 GA. L. REV. 259 (1984); Scott O. Wright \& Joseph A. Colussi, The Successful Use of the Class Action Device in the Management of the Skywalks Mass Tort Litigation, 52 UMKC L. REV. 141 (1984). 
damages standards. Punitive damage standards can range from gross negligence to reckless disregard to various levels of willfulness and wantonness." ${ }^{39}$ In the Simon II litigation, Judge Weinstein attempted to solve the choice-of-law problem by determining that a single state's law could apply to all punitive damage claims, ${ }^{40}$ or alternatively by subclassing. ${ }^{41}$ On appeal, the Second Circuit invalidated Judge Weinstein's certification of a Rule 23(b)(1)(B) punitive damage class, but did not reach the question of whether the court could legitimately apply one state's law to a punitive damage class. ${ }^{42}$ However, federal courts have rejected attempts to resolve the punitive damage choice-oflaw problem through the subclassing mechanism. ${ }^{43}$ Consequently, applicable law problems for proposed multistate punitive damage classes still remain, and present a significant obstacle to class certification of punitive damage classes under any Rule 23 provision.

A fourth reason courts have denied class certification of a proposed 23(b)(1)(B) punitive damage class has been grounded in the determination that a proposed class is underinclusive. The paradigmatic case illustrating the under inclusive principle is the School Asbestos litigation. $^{44}$ In that action, the plaintiffs-school districts throughout the United States that had abated asbestos materials from school buildings-sought certification of a Rule 23(b)(1)(B) punitive damage class. $^{45}$ The district court granted certification, but the Third Circuit reversed, concluding that the effect of the mandatory class was to single out school districts "for special and possibly disadvantageous treatment." 46 The Third Circuit noted that there were thousands of other potential asbestos claimants not embraced by the class definition, who had the ability to seek exemplary damages from the defendants. These claimants could seek damages without being subject to the strictures of a mandatory class, and therefore the quest for damages could devolve into

39. Dalkon Shield, supra note 3, 693 F.2d at 850.

40. In re Simon II Litig., 211 F.R.D. 86, 166-79 (E.D.N.Y. 2002) vacated 407 F.3d 125 (2d Cir. 2005).

41. Id. at $178-79$

42. In re Simon II Litig., 407 F.3d 125, 140 (2d Cir. 2005); see also Hines, supra note 14, at 916-20.

43. See, e.g., In re Telectronics Pacing Sys., Inc., 172 F.R.D. 271, 294 (S.D. Ohio 1997) (finding that "proposed punitive damages subclasses fail to satisfy Rule 23(b)"); see also Hines, supra note 14, at 917-18 ("Citing these state law variations, a number of courts have rejected class treatment of punitive damages liability.").

44. In re Sch. Asbestos Litig., 789 F.2d 996 (3d Cir. 1986).

45. Id. at $998-99$.

46. Id. at 1006 . 
a race to the courthouse among competing claimants. ${ }^{47}$ Similar to the Anti-Injunction rationale disallowing punitive damage classes, the underinclusiveness principle also failed to gain considerable traction as a theory for deflecting proposed punitive damage classes.

Finally, a fifth reason for repudiation of a proposed Rule 23(b)(1)(B) damage class is based on the theory that a defendant may not utilize this class device to circumvent bankruptcy procedures, or to involuntarily modify one creditor's rights against another. ${ }^{48}$ The paradigmatic case is the In re Joint Eastern and Southern District Asbestos Litigation (In re Keene Corp.), where the Second Circuit reversed Judge Weinstein's certification of a Rule 23(b)(1)(B) mandatory limited-fund class. ${ }^{49}$

Although the Keene class certification did not involve a request for a punitive damage class, the appellate decision is nonetheless instructive concerning judicial limitations on the limited-fund class action. In an unusual scenario, the Keene Corporation preemptively sought to resolve all its asbestos liabilities by securing certification of a mandatory settlement class. ${ }^{50}$ In order to provide an evidentiary basis for the existence of the limited fund, Judge Weinstein appointed a special master to make findings of the limited fund, which the master did. ${ }^{51}$ On appeal, the Second Circuit rejected this attempt to resolve the corporation's liabilities through preemptive certification of a mandatory, limited-fund class action. Referencing the Bankruptcy Act, the Court rejected the Keene Corporation's arguments on behalf of the 23(b)(1)(B) class action "because [the arguments were] a self-evident evasion of the exclusive legal system established by Congress for debtors to seek relief."

\section{B. Successful Punitive Damage Classes}

Notwithstanding the cluster of reported decisions rejecting proposed punitive damage class actions, courts historically have approved punitive

47. Id.

48. See In re Joint E. \& S. Dist. Asbestos Litig. (In re Johns-Manville Corp.), 982 F.2d 721 (2d Cir. 1992) (disallowing use of a Rule 23(b)(1)(B) class action to circumvent bankruptcy laws). But cf. Coburn v. 4-R Corp., 77 F.R.D. 43 (E.D. Ky. 1977) (certification of Rule 23(b)(1)(B) class action where likelihood of aggregation of all claims against the defendant would render the defendant insolvent).

49. 14 F.3d 726 (2d Cir. 1993). But cf. In re Joint E. \& S. Asbestos Litig. (In re JohnsManville Corp.), 982 F.2d at 741 (upholding Rule 23(b)(1)(B) limited-fund class certification); In re Joint E. \& S. Dist. Asbestos Litig. (In re Eagle-Picher Indus.), 134 F.R.D. 32, 34 (E.D.N.Y. 1990) (same).

50. Keene, 14 F.3d at 732 .

51. Id. at 729 .

52. Id. at 732 . 
damage classes in an equally small universe of cases. These cases fall into two categories: (1) punitive damage class actions certified pursuant to Rule 23(b)(3), and (2) punitive damage classes approved pursuant to 23(b)(1)(B). ${ }^{53}$ Typical of both sides of this debate, proponents of the punitive damage class tend to overstate the quantum of these decisions, as well as their precedential value and significance. ${ }^{54}$ As I suggest below, when all is said, done, and thoroughly analyzed, proponents of the punitive damage class basically have two viable precedents upon which to hang their hats: Hilao v. Estate of $\operatorname{Marcos}^{55}$ and In re Exxon Valdez. ${ }^{56}$ In addition, the Ninth Circuit's recent decision in Dukes $v$. Wal-mart, Inc. establishes a possible precedent for a Rule 23(b)(2) punitive damage class, although this decision currently is on appeal for rehearing en banc. ${ }^{57}$

\section{Rule 23(b)(3) Punitive Damage Classes Approved}

Proponents of the punitive damage class cite to a litany of decisions familiar to mass-tort litigation attorneys: Jenkins v. Raymark Industries, Inc. ${ }^{58}$ Watson v. Shell Oil Co., ${ }^{59}$ and Hilao v. Estate of Marcos. ${ }^{60}$ These

53. Certification of punitive damage class actions under the Rule 23(b)(2) provision are extremely rare. But see Dukes v. Wal-mart, Inc., 509 F.3d 1168, 1188-89 (9th Cir. 2007) (affirming certification of a Rule 23(b)(2) class for injunctive and declaratory relief, back pay, and punitive damages), reh'g en banc granted, 556 F.3d 919 (9th Cir. 2009). The Dukes decision is discussed infra at Part II.B.3. The Rule 23(b)(2) category for class certification embraces injunctive and declaratory relief. Historically, the Rule 23(b)(2) class action has not embraced actions for compensatory damages. The federal circuits currently apply different standards to determine whether class members may recover damages in a 23(b)(2) class action. See, e.g., Molksi v. Gleich, 318 F.3d 937, 950 (9th Cir. 2003) (applying ad hoc subjective intent test); Robinson v. Metro-N Commuter R.R., 267 F.3d 147, 165 (2d Cir. 2001) (same); Allison v. Citgo Petroleum Corp., 151 F.3d 402, 411 (5th Cir. 1998) (applying bright-line test; requiring that injunctive or declaratory relief predominates to certify 23(b)(2) action and damages permitted only when "incidental" to the predominant injunctive relief); see also Underwood, supra note 1, at 786. Compare Nelson v. Walmart Stores, Inc., 245 F.R.D. 358, 380 (E.D. Ark. 2007) (refusing to certify punitive damage class under either Rule 23(b)(2) or 23(b)(3)), with Palmer v. Combined Ins. Co., 217 F.R.D. 430, 438-41 (N.D. Ill. 2003) (certifying class in discrimination suit involving both equitable relief and punitive damages).

54. See, e.g., Underwood, supra note 1, at 798 ("Opponents of the punitive damage class action are too quick to disregard the many examples of such certified classes and to strain to read between the lines in finding some message of abandonment of the device.").

55. 103 F.3d 767 (9th Cir. 1996).

56. 26 F.3d 130 (9th Cir. 1994).

57. See discussion infra Part II.B.3.

58. 782 F.2d 468 (5th Cir. 1986) (affirming trial court certification of Rule 23(b)(3) class action trial plan and bifurcated trial of compensatory and punitive damages).

59. 979 F.2d 1014 (5th Cir. 1992), aff'g Adams v. Shell Oil Co. (In re Shell Oil Co.), 136 F.R.D. 588, 590 (E.D. La. 1991) (certifying 23(b)(3) class).

60. 103 F.3d 767 (9th Cir. 1996) (approving Rule 23(b)(3) class certification with bifurcated 
cases all predate Ortiz. Jenkins, Watson, and Hilao each involved class certification pursuant to Rule 23(b)(3). Obviously, if the Jenkins line of authority were asserted today in support of certification of a punitive damage class, such Rule 23(b)(3) classes would not be subject to Ortiz's limited-fund requirements.

Notwithstanding Ortiz and subsequent judicial developments, proponents of the punitive damage class continue to cite to the Jenkins line of authority as support for the proposition that punitive damage classes have been approved in the past and are equally tenable today. ${ }^{61}$ However, properly construed, the Jenkins-Watson-Hilao line of authority provides problematic support for the punitive damage class, especially after the Fifth Circuit's decision in Cimino v. Raymark Industries, Inc. where the court reexamined its prior enthusiasm for exotic trial plans, statistical extrapolation of damages, and punitive damage classes. ${ }^{62}$ In addition, other commentators ${ }^{63}$ have suggested that the reverse-bifurcated trial plans approved in these cases cannot withstand scrutiny under the Supreme Court's decisions in State Farm Mutual Automobile Insurance Co. v. Campbell ${ }^{64}$ and Phillip Morris USA v. Williams. ${ }^{65}$

Moreover, it is perhaps worth noting that in none of these cases did a court actually certify a punitive damage class. ${ }^{66}$ Instead, the courts certified conventional Rule 23(b)(3) compensatory damage classes, which included a multiphase, reverse-bifurcated trial structure for

trial plan with classwide trial of punitive damages).

61. See Underwood, supra note 1, at 797-807.

62. 151 F.3d 297, 335 (5th Cir. 1998) (disapproving certification of a Rule 23(b)(3) asbestos class based on a multi-phase trial using statistical extrapolation to determine damages, with phase I based on the Jenkins model).

63. See, e.g., Victor E. Schwartz \& Christopher E. Appel, Putting the Cart Before the Horse: The Prejudicial Practice of a "Reverse Bifurcation" Approach to Punitive Damages, 2 ChARLESTON L. ReV. 375, 397, 400 (2008) (arguing that determining punitive damages before compensatory damages raises serious constitutional issues and violates procedural due process "because it leaves the jury to determine a punitive damages ratio without a nexus to the defendants' conduct toward any particular plaintiff or group of plaintiffs"); Byron G. Stier, Now It's Personal: Punishment and Mass Tort Litigation After Philip Morris v. Williams, 2 CHARLESTON L. Rev. 433, 445-46 (2008) ("By stating that due process requires punitive damages to be based on the harm to particular plaintiffs whose evidence is before the jury, Philip Morris suggests that these punitive-first class trial plans will offend due process-neither the multiplier nor lump-sum approach allows the defendant to offer every available defense, nor provides sufficient information on the extent of harm to those other than the class representatives, such that the punitive award can be said to bear a 'reasonable relationship' to compensatory damages.").

64. 538 U.S. 408 (2003).

65. 127 S. Ct. 1057 (2007).

66. This is unlike cases in which the parties seek certification of a punitive damage class pursuant to Rule 23(b)(1)(B) on the limited fund theory. 
determining classwide punitive damages based on a multiplier. ${ }^{67}$ Finally, it is also perhaps worth noting that no classwide determination or award of punitive damages was actually ever made either in Jenkins or Watson.

In Jenkins, the Fifth Circuit upheld certification of a 23(b)(3) class of asbestos claimants, based on a novel three-phase trial plan. ${ }^{68}$ In the first phase, the jury was to make a classwide determination of common liability and defense issues - most notably the applicability of the "stateof-the-art" defense. ${ }^{69}$ In addition, the jury was to determine a punitive damage multiplier. ${ }^{70}$ In the second phase, the claims of individual class representatives would be tried. ${ }^{71}$ Finally, in a third phase, the individual issues of class members would be resolved in subsequent mini-trials of four to ten plaintiffs. ${ }^{72}$ This model trial plan conventionally has been denominated as a "reverse-bifurcated" trial plan because a jury effectively is called upon to determine dispositive defenses and liability for punitive damages, before a jury determination of actual, compensatory damages.

Building on this model, the Fifth Circuit again approved the technique of a classwide punitive damage multiplier (before trial of compensatory damages) in Watson, ${ }^{73}$ and the Ninth Circuit relied on Jenkins in approving a multiphase trial plan, including classwide punitive damages, in Hilao. ${ }^{74}$

Whether the Jenkins-Watson-Hilao trilogy provides robust doctrinal support for certification of a Rule 23(b)(3) punitive damage class today

67. Elizabeth Cabraser and Robert Nelson make the interesting argument that Jenkins, although decided more than twenty years ago, may have continuing viability after Ortiz and Phillip Morris "because of its prescient approach to the punitive damages 'ratio' issue." Cabraser \& Nelson, supra note 4 , at 422 .

68. Jenkins v. Raymark Indus., Inc., 782 F.2d 468 (5th Cir. 1986).

69. Jenkins v. Raymark Indus., Inc., 109 F.R.D. 269, 281-82 (E.D. Tex. 1985)

70. Id. at 282 .

71. Id

72. $I d$.

73. Watson v. Shell Oil Co., 979 F.2d 1014, 1017 (5th Cir. 1992). In Watson, the district court approved a Rule 23(b)(3) trial plan consisting of four phases. Id. at 1017-18. Phase I would resolve common issues of liability and punitive damages. Id. at 1018. In Phase II, a jury would determine liability for compensatory damages in twenty fully-tried individual class representatives' cases. Id. In Phase III, a different jury would resolve issues of compensatory damages, such as causation and quantum. Id. Phase IV provided for the district court's computing of punitive damages. Id. The Fifth Circuit approved the trial plan as to punitive damages. Id. at 1018-21.

Relying on both Jenkins and Watson, the District Court for the Eastern District of Louisiana certified a punitive damage class pursuant to Rule 23(b)(3). Castano v. Am. Tobacco Co., 160 F.R.D. 544, 560 (E.D. La. 1995). This class certification was reversed by the Fifth Circuit. 84 F.3d 734, 752 (5th Cir. 1996).

74. Hilao v. Estate of Marcos, 103 F.3d at 767, 782 (9th Cir. 1996). The Hilao trial plan called for a three-phase trial modeled on Jenkins. Id. 
seems questionable, especially in light of subsequent judicial developments. Of significance, and as plaintiffs' attorneys conceded, after the initial appellate victory "the Jenkins litigation went downhill." 75 After a number of days at trial, the Jenkins class action was settled and the court never actually implemented the novel trial plan approved by both the district and appellate court. ${ }^{76}$ The Fifth Circuit's decision in Jenkins was further undermined in both In re Fibreboard Corp. ${ }^{77}$ and Cimino. $^{78}$

Similarly, Watson is problematic for advocates who wish to rely on this decision as an endorsement of the punitive damage class because not only did litigants in Watson settle, but the Watson decision technically was vacated on appeal. ${ }^{79}$ After the Fifth Circuit initially endorsed the Watson class certification and trial plan, the defendants petitioned and were granted rehearing en banc. ${ }^{80}$ Faced with the prospect of appellate review by the entire Fifth Circuit, the parties settled. ${ }^{81}$ As a consequence of the settlement, the Watson judgment was vacated and the full panel of the Fifth Circuit never opined on the propriety of the Watson trial plan. ${ }^{82}$ Consequently, the Watson decision has remained a source of contested authority concerning its precedential value. ${ }^{83}$

There are further reasons to question the precedential value of Jenkins and Watson as authority for endorsement of the Rule 23(b)(3) punitive damage class. Both the Jenkins and Watson classes were relatively small and geographically circumscribed classes. The Jenkins

75. Cabraser \& Nelson, supra note 4, at 423. Cabraser and Nelson suggest that after the Jenkins certification order was affirmed, "the trial court struggled to maintain a class-wide structure through successive phases of injury, specific causation, and damages determinations." Id.

76. See In re Raymark Indus., Inc., 831 F.2d 550, 553 (5th Cir. 1987) (affirming the district courts' approval of the settlement).

77. 893 F.2d 706, 712 (5th Cir. 1990) (finding that a class of a trifurcated trial plan could not be certified).

78. Cimino v. Raymark Indus., Inc., 151 F.3d 297 (5th Cir. 1998) (reversing judgment of phase III of a trifurcated plan).

79. See Castano v. Am. Tobacco Co., 160 F.R.D. 544, 558 n.15 (E.D. La. 1995) ("The Court understands that the Watson judgment was vacated by the grant of rehearing en banc and that the case settled thereafter without the Fifth Circuit having an opportunity to opine on the propriety of the panel decision. . . Nevertheless, the Court finds Watson persuasive in light of the prior Fifth Circuit discussion in Jenkins.").

80. Watson v. Shell Oil Co., 979 F.2d 1014 (5th Cir. 1992), reh'g en banc granted, 990 F.2d 805 (5th Cir. 1993), appeal dismissed, 53 F.3d 663 (5th Cir. 1994).

81. Castano, 160 F.R.D. at 558 n. 15.

82. Id.

83. Notwithstanding this procedural history, Watson continues to be cited by proponents of the punitive damage class in support of judicial approval of this mechanism. For criticisms of the Fifth Circuit's original panel decision in Watson, see Hines, supra note 14, at 939-41. 
class was limited to asbestos claimants in the Eastern District of Texas, ${ }^{84}$ and the Watson class was limited to claimants exposed to injuries resulting from an oil refinery explosion in Louisiana. ${ }^{85}$ Consequently, neither court in Jenkins or Watson was confronted with sprawling multistate or nationwide classes that would have required the courts to consider applicable-law issues, and whether such applicable-law complications would have undermined the predominance and superiority requirements of Rule 23(b)(3). The Watson litigation involved a localized mass-accident case, with claims brought solely under Louisiana law. ${ }^{86}$ Because of the localized nature of the underlying events, the Louisiana court was able to justify the Jenkins-style trial plan with a punitive damage phase, determining that the defendant's single course of conduct — causing injury to all the plaintiffs — was identical for each class member. ${ }^{87}$

Hilao, then, remains the sole example of a 23(b)(3) class action for compensatory and punitive damages that was certified, actually tried, and resulted in quantifiable damages to the class claimants. ${ }^{88}$ In Hilao and its preceding litigation the Ninth Circuit upheld a Jenkins-style trifurcated trial plan that permitted punitive damages to be assessed prior to the determination of actual compensatory damages. ${ }^{89}$

The Hilao decision, however, also presents a challenging precedent for advocates of the punitive damage class. ${ }^{90}$ The Ninth Circuit's various holdings approving this Rule 23(b)(3) compensatory and punitive damage class may be cabined by various distinguishing facts. Unlike most federal diversity-based mass-tort cases, the Hilao litigation was pursued under the federal Alien Torts Claim Act, ${ }^{91}$ and involved alleged egregious violations of human rights, including murder, torture, genocide, and disappearance. $^{92}$ As such, the Hilao litigation was freighted with sympathetic political implications compelling some forum for palliative justice. ${ }^{93}$ The class members as well as the defendant were

84. Jenkins v. Raymark Indus., Inc., 782 F.2d 468, 470 (5th Cir. 1986).

85. Watson v. Shell Oil Co., 979 F.2d 1014, 1016-17 (5th Cir. 1992).

86. Id. at 1017 .

87. Id. at 1019 .

88. Class members were awarded $\$ 750$ million in compensatory damages and $\$ 1.2$ billion in exemplary damages. See Hilao v. Estate of Marcos, 103 F.3d 762, 763 (9th Cir. 1996).

89. See Hilao, 103 F.3d at 767; In re Estate of Ferdinand Marcos, Human Rights Litigation 25 F.3d 1467, 1480 (9th Cir. 1994).

90. For doctrinal criticism of the Ninth Circuit's approval of Hilao, see Hines, supra note 14, at $941-42$.

91. Estate of Ferdinand Marcos, 25 F.3d at 1468-69.

92. Id. at 1472 .

93. See generally id. ("Marcos's acts of torture, execution, and disappearance were clearly acts 
all foreign nationals. ${ }^{94}$ The defendant was the estate of a deposed despot. $^{95}$ Moreover, the court essentially glossed over choice-of-law issues embedded in the class action ${ }^{96}$ in an effort to construct an administrative model for compensating egregious human-rights violations. ${ }^{97}$ The Ninth Circuit endorsed the concept of a reversetrifurcated trial plan, which may not withstand scrutiny today. Finally, the Ninth Circuit chose to ignore and deflect the Fifth Circuit's decision in Cimino that disapproved the statistical extrapolation of compensatory damages in a multiphase trial, aligning instead with Jenkins and Watson in approving the Hilao trial plan. ${ }^{98}$

Leading proponents of the viability of the punitive damage class today have accurately noted that 'Jenkins' $[\mathrm{s}]$ original concept of the Phase I, class-wide punitive damage determination, and the calculation of a uniform ratio based upon the class-wide jury's assessment of the defendants' conduct, was never reversed." 99 As such, these advocates impliedly suggest that Jenkins, Watson, and Hilao remain compelling authority for certifying Rule 23(b)(3) punitive damage classes based on reverse-bifurcated trial plans. However, the novel trial plans endorsed in Jenkins, Watson, and Hilao were never reviewed by the Supreme Court. And, post-Jenkins, proposed punitive damage class actions have foundered on conventional Rule 23(b)(3) grounds, such as lack of predominance, superiority, and manageability. ${ }^{100}$

Moreover, the three appellate decisions in Jenkins, Watson, and Hilao were rendered before the Supreme Court's rulings in State Farm v.

outside his authority as President.”).

94. Id. at $1467-70$.

95. Id. at 1469.

96. See id. at 1472-73. The Ninth Circuit upheld the district court's determination to apply a combination of federal common law and Philippine law to the claims. Id. at 1473.

97. See id. at 1471-73.

98. See generally Hilao v. Estate of Marcos, 103 F.3d 782 (9th Cir. 1996) (affirming trial plan); In re Estate of Marcos Human Rights Litig., 910 F. Supp. 1460, 1461, 1463-68 (D. Haw. 1995) (describing trifurcated trial plan and statistical extrapolation for compensatory damages); see also Cimino v. Raymark Indus., Inc., 151 F.3d 297, 319-21 (5th Cir. 1998); Jenkins v. Raymark Indus., Inc., 782 F.2d 468, 470 (5th Cir. 1986).

99. Cabraser \& Nelson, supra note 4 , at 423.

100. See e.g., Williams v. Telespectrum, Inc., No. 3:05cv853, 2007 WL 6787411, at *19-23 (E.D. Va. June 1, 2007) (denying Rule 23(b)(3) class certification partly because of due process concerns with class-wide punitive damage adjudication); O'Neal v. Wackenhut Servs., Inc., No. 3: 03-cv-397, 2006 WL 1469348, at *68-69 (E.D. Tenn. May 25, 2006) (denying class certification because court would have to engage in numerous individualized mini-trials to determine whether each class member should receive punitive damages); Carlson v. C.H. Robinson Worldwide, Inc., No. 02-3780, 2005 WL 758602, at*49-50 (D. Minn. Mar. 31, 2005) (denying class certification because individualized fact determinations required to calculate punitive damages would undermine manageability). 
Campbell and Philip Morris v. Williams. Arguably, the Court's evolving punitive damage jurisprudence announced in these cases has placed constitutional due process constraints on a collision course with Jenkinsstyle trial plans, so central to certification of a Rule 23(b)(3) punitive damage class. Hence, the continued vitality of the 23(b)(3) punitive damage class, based on reverse-bifurcated trial plans, is inexorably linked with the Court's evolving punitive damage jurisprudence.

\section{Rule 23(b)(1)(B) Punitive Damage Classes Approved}

Similar to the Jenkins line of authority, proponents of the punitive damage class routinely cite a litany of cases to demonstrate that federal courts historically have certified punitive damage class actions under the Rule 23(b)(1)(B) provisions. ${ }^{101}$ Chief among this small universe of cases are district-court class certifications in the Dalkon Shield, ${ }^{102}$ School Asbestos, ${ }^{103}$ and Agent Orange ${ }^{104}$ litigations. However, even as proponents sometimes grudgingly note, the Dalkon Shield and Asbestos School certifications did not survive appellate review. ${ }^{105}$ This historical account is further muddied because the much-cited Agent Orange Rule 23(b)(1)(B) certification is itself of questionable pedigree as a precedent for the 23(b)(1)(B) punitive damage class. ${ }^{106}$ And, as commentators note, these historical examples of Rule 23(b)(1)(B) all predate the Supreme Court's decision in Ortiz, as well as the Court's evolving

101. See e.g., Nagy, supra note 14, at 610 ("Prior to State Farm, only a handful of mandatory punitive damage classes had been certified under 23(b)(1)(B).").

102. In re N. Dist. of Cal. Dalkon Shield IUD Prods. Liab. Litig., 521 F. Supp. 1188 (N.D. Cal. 1981).

103. In re Asbestos Sch. Litig., 104 F.R.D. 422, 434 (E.D. Pa. 1984).

104. In re "Agent Orange" Prod. Liab. Litig., 580 F. Supp. 690, 705-13 (E.D.N.Y. 1984)

105. See In re Sch. Asbestos Litig., 789 F.2d 996, 1004-05 (3d Cir. 1986) (reversing the Rule 23(b)(1)(B) class certification); Dalkon Shield, supra note 3, 693 F.2d at 852 (same).

106. In the usual rendering of the Agent Orange litigation, proponents of the punitive damage class point to vindication by the Second Circuit of the (b)(1)(B) punitive damage class in In re Diamond Shamrock Chems. Co., 725 F.2d 858, 862 (2d Cir. 1984). See, e.g., Nagy, supra note 14, at $610 \mathrm{n} .89$. However, the actual history of the Agent Orange punitive damage class certification is much more complicated and nuanced. As Professor Hines has noted, the Second Circuit in Diamond Shamrock refused to issue a writ of mandamus decertifying the punitive damage class, but this does not amount to appellate approval of the certification. See Hines, supra note 14, at 905 n.83. Ultimately, the parties in Agent Orange settled the litigation pursuant to a Rule 23(b)(3) opt-out class, which settlement excluded punitive damages. On direct appeal to the Second Circuit of various aspects of the settlement, the Second Circuit concluded that it "need not address the propriety of the certification of a mandatory class under Rules 23(b)(1)(B)." In re "Agent Orange" Prods. Liab. Litig., 818 F.2d 145, 167 (2d Cir. 1987). But cf. In re Joint E. \& S. Dists. Asbestos Litig., 982 F.2d 721, 736-37 (2d Cir. 1992) (repudiating class certification of a Rule 23(b)(1)(B) class in bankruptcy, but construing Diamond Shamrock to imply approval of (b)(1)(B) certification on a limited punishment theory). 
jurisprudence articulating the constitutional parameters for punitive damage awards. ${ }^{107}$ Consequently, any remaining authority of these historical, pre-Ortiz Rule 23(b)(1)(B) punitive damage class certification decisions seems entirely strained.

Instead, the Exxon Valdez litigation provides the most viable contemporary illustration of a Rule 23(b)(1)(B) punitive damage class. ${ }^{109}$ Remarkably, the Exxon Valdez litigation spans nearly two decades. The events underlying this litigation occurred in 1989, when the Exxon Valdez ran aground in the Prince William Sound in Alaska, resulting in an oil spill affecting thousands of Alaskans. The federal district court certified a Rule 23(b)(1)(B) class in $1994 .^{110}$ In 2008, nearly twenty years after the oil spill, the Supreme Court issued its opinion, in Exxon Shipping Co. v. Baker, upholding the availability of punitive damages pursuant to federal maritime law, but severely limiting the quantum of those damages to a one-to-one ratio of compensatory to punitive damages. ${ }^{111}$

As is well-known, the procedural history of the Exxon Valdez litigation is notable because the litigants and the federal district court

107. See, e.g., Hines, supra note 14, at 906 n.84 ("Of course, these cases all pre-date the Supreme Court's recent jurisprudence articulating substantive due process limits on the imposition of punitive damages, which might provide more compelling grounds to proceed with a limited punishment class.").

108. For a balanced assessment of these precedents, see Cabraser \& Nelson, supra note 4, at 422 \& n.41 ("Historically, while their rationale appears compelling, punitive damage class actions have achieved mixed results. Class actions focusing on punitive damage claims have most frequently sought certification under Fed. R. Civ. P. 23(b)(1)(B), commonly known as the 'limited fund' class provision. The proof of a limited fund has always been exacting, and became more so in 1999 with the United States Supreme Court's decision in Ortiz v. Fibreboard.").

Another pre-Ortiz attempt to certify a Rule 23(b)(1)(B) punitive damage class similarly provides weak support for the viability of the punitive damage class pursuant to that provision. See In re Silicone Gel Breast Implants Prods. Liab. Litig., 887 F. Supp. 1469 (N.D. Ala. 1995). In the breast implant litigation, the plaintiffs sought certification and approval of a conventional Rule 23(b)(3) opt-out compensatory global damage class settlement, in the amount of $\$ 4$ billion. In turn, the defendant, Dow Corning, sought certification of a Rule 23(b)(1)(B) punitive damage class, to insulate itself from potential repetitive punitive damages awards to claimants who opted out of the Rule 23(b)(3) class. The plaintiffs objected to the defendant's proposal for the mandatory class, and the federal district court denied Dow Corning's request. As a consequence, Dow subsequently withdrew from the proposed settlement and filed for bankruptcy. For a narrative of these events, see Cabraser \& Nelson, supra note 4, at 424-25.

109. In re Exxon Valdez, 490 F.3d 1066 (9th Cir. 2007). The Simon II tobacco litigation in the Eastern District of New York provides the other post-Ortiz attempt to certify a Rule 23(b)(1)(B) punitive damage class, which the Second Circuit repudiated. In re Simon II Litig., 211 F.R.D. 86 (E.D. N.Y. 2002), vacated 407 F.3d 125 (2d Cir. 2005). The Simon II decision is discussed infra at notes $176-97$ and accompanying text.

110. Decision Regarding Certification of a Mandatory Punitive Damages Class, In re Exxon Valdez, 490 F.3d 1066 (D. Alaska Mar. 8, 1994), (Order No. 180, No. A89-0095-CV) [hereinafter Certification Decision, Exxon Valdez].

111. 128 S. Ct. 2605 (2008). 
found themselves whip-sawed by the Supreme Court's developing punitive damage jurisprudence. ${ }^{12}$ After certification of a Rule 23(b)(1)(B) class, the Exxon case was tried to a jury in 1994 in a multiphase trial that determined liability for compensatory damages first, followed by a classwide determination of punitive damages. ${ }^{113}$ The jury returned a classwide verdict of punitive damages in the amount of $\$ 5$ billion. However, the jury returned its original punitive damage award prior to the Supreme Court's punitive damage decisions in $B M W v$. Gore, ${ }^{114}$ Cooper v. Leatherman, ${ }^{115}$ and State Farm v. Campbell. ${ }^{116}$

Consequently, Exxon appealed the $\$ 5$ billion punitive damage award twice to the Ninth Circuit, and in both instances the appellate court remanded to the district court for recalculation of the punitive damage award in light of the Supreme Court's evolving jurisprudence. ${ }^{117}$

The Exxon Valdez litigation saga, then, has always focused on issues relating to the availability of punitive damages and application of appropriate standards for determining a constitutionally sustainable quantum of damages. ${ }^{118}$ During the Exxon Valdez's lengthy odyssey through the judicial system, at no time was the class certification pursuant to Rule 23(b)(1)(B) challenged, contested, or subject to appellate scrutiny. Consequently, the district court's approval of the Rule 23(b)(1)(B) punitive damage class remains a signal illustration of a successful punitive damage class certification.

The Exxon Valdez punitive damage class certification is significant for several reasons. The defendant, rather than the plaintiffs, sought certification of the mandatory punitive damage class. ${ }^{119}$ Exxon requested this certification based on the "limited punishment" theory of punitive damages. ${ }^{120}$ The district court rejected plaintiffs' arguments that due process could be satisfied by informing juries in any individual case of previous punitive damage awards, but was instead concerned that the

\footnotetext{
112. See Cabraser \& Nelson, supra note 4, at 423-24; Hines, supra note 14, at 907-09.

113. In re Exxon Valdez, 296 F. Supp. 2d 1071, 1079-80 (D. Alaska 2004).

114. BMW of N. Am., Inc. v. Gore, 517 U.S. 559 (1996).

115. Cooper Indus., Inc. v. Leatherman Tool Group, Inc., 532 U.S. 424 (2001).

116. State Farm Mut. Auto. Ins. Co. v. Campbell, 538 U.S. 408 (2003).

117. See In re Exxon Valdez, 490 F.3d 1066, 1095 (9th Cir. 2007) (reducing the punitive damage award to $\$ 2.5$ billion); In re Exxon Valdez, 270 F.3d 1215, 1241 (9th Cir. 2001); see also In re Exxon Valdez, 296 F. Supp. 2d 1071 (D. Alaska 2004) (applying State Farm and BMW guidelines retroactively; finding 1994 jury instructions comported with State Farm requirements imposed in 2003; recalculating punitive damage award to $\$ 4.5$ billion).

118. See Cabraser \& Nelson, supra note 4, at 423-24.

119. Certification Decision, Exxon Valdez, supra note 110, at 8.

120. Hines, supra note 14, at 908 (citing Certification Decision, Exxon Valdez, supra note 110,
} at 8.) 
defendant could be excessively punished by being subjected to multiple, repetitive punitive damage awards. ${ }^{121}$ The district court thus agreed with Exxon and granted certification based on a limited fund and limited punishment rationale, partially relying on the Court's then-prevailing punitive damage decisions in TXO v. Alliance ${ }^{122}$ and Pacific Mutual Life v. Haslip. ${ }^{123}$ The district court construed $T X O$ and Haslip as placing substantive due process limits on punitive damages by placing reasonable limits on punishment. ${ }^{124}$

Moreover, the Rule 23(b)(1)(B) punitive damage class certification in the Exxon Valdez litigation is factually distinctive because the federal court enjoyed a "high degree of deference and cooperation" with the Alaskan state courts in resolving the Exxon Valdez claims, ${ }^{125}$ and therefore never issued an injunction restraining parallel state court litigation. ${ }^{126}$ Such an injunction might have vitiated the Rule 23(b)(1)(B) class certification pursuant to the Federal Skywalk Anti-Injunction principle.

Similar to the Ninth Circuit's approval of the Rule 23(b)(3) class in Hilao, the Exxon Valdez class certification of a Rule 23(b)(1)(B) punitive damage class provides a problematic precedent for the punitive damage class. First, it is highly unusual for a defendant to seek certification of a

121. Certification Decision, Exxon Valdez, supra note 110, at 10 n.9. The district court was concerned that unfairness would result as a consequence of individual punitive damage trials, which opened the possibility that early successful litigants could reap a windfall at the expense of laterfiling claimants. See Hines, supra note 14, at 908

122. See TXO Prod. Corp. v. Alliance Res. Corp., 509 U.S. 443 (1993).

123. See Pacific Mut. Life Ins. Co. v. Haslip, 499 U.S. 1 (1991); see also Hines, supra note 14, at 908 (describing the district court's reliance on Haslip and the court's recent punitive damage jurisprudence).

124. The district court, in certifying the Rule 23(b)(1)(B) class, noted that "recent developments in the law have, in substance, created a limited fund for punitive damages in multi-claim cases," and that these are "substantive limits beyond which penalties may not go," without violating the Due Process Clause of the Fourteenth Amendment. See Certification Decision, Exxon Valdez, supra note 110, at 8 . The court further opined:

From the case law it is apparent that the defendant's assets are not the only consideration which may limit a punitive damage award. Substantive due process also limits punitive damages by placing reasonable limits on punishment. A defendant with tremendous assets, such as Exxon, does not face unlimited punitive damages. Rather due process places a limit on punitive damages, and, in substance, creates a limited fund from which punitive damages may be awarded. Id. at 9 .

125. See id. at 11. As indicated earlier, the Ninth Circuit rebuffed a challenge to the Exxon Valdez certification based on the Federal Skywalk Anti-Injunction theory. See In re Exxon Valdez, 26 F.3d 130 (9th Cir. 1994) (unpublished table decision).

126. The Alaskan courts apparently extended just such deference and comity to the federal proceedings, and rejected punitive damage claims in parallel state court actions. See In re Exxon Valdez, 229 F.3d 790, 793 (9th Cir. 2000) (citing Chenega Corp. v. Exxon Corp., 991 P.2d 769, 775 (Alaska 1999). 
mandatory Rule 23(b)(1)(B) punitive damage class, ${ }^{127}$ but the Exxon Valdez litigation illustrates why future defendants in egregious cases might want to pursue this course.

One can only surmise that, faced with a really bad set of underlying facts $^{128}$ and thousands of really, really angry Alaskans, the Exxon Corporation made the strategic decision to cabin its own liability through a classwide trial of compensatory and punitive damages. The mandatory punitive class essentially permitted Exxon to mitigate its punishment in one substantial lash, rather than dying painfully from a thousand repetitive lashes. ${ }^{129}$ In this regard, the mandatory punitive damage class resembled the civil equivalent of criminal plea bargaining - it enabled Exxon to bid down its own punishment. ${ }^{130}$

Other characteristics of the Exxon Valdez litigation qualify the general applicability of this successful Rule 23(b)(1)(B) certification. Exxon Valdez concerned a classical environmental mass-accident case that was geographically limited, and subject to one body of federal maritime common law. ${ }^{131}$ Consequently, the Exxon Valdez provides an uncertain precedent for sprawling, nationwide products-liability masstort cases. $^{132}$ As indicated above, because the federal and state courts amicably permitted the litigant to proceed in federal court, the certified class was not vulnerable to an Anti-Injunction Act challenge. Moreover, in the Exxon Valdez trial, the jury first rendered a compensatory damage verdict in favor of the class before proceeding to determine punitive damages for the same class. ${ }^{133}$ As such, the Exxon Valdez class

127. But see In re Silicone Gel Breast Implants Prod. Liab. Litig., 887 F. Supp. 1469 (N.D. Ala. 1995) (Defendant Dow Corning sought certification of a mandatory Rule 23(b)(1)(B) punitive damage class and was rebuffed by the district court).

128. Chief among those facts were an admittedly drunken sea captain and a huge amount of dead fish and birds. See Alaska Oil Spill COMmission, Final Report: THE Wreck of the EXXON VALDEZ, 5-14 (1990), http://www.evostc.state.ak.us/facts/details.cfm.

129. See Fisher, supra note 14, at 6 (analogizing between civil and criminal punishment and arguing that courts should accede to legislative determinations to impose substantial punitive damage awards, in the same way courts regularly accede to legislative determinations to impose exceptionally severe criminal punishment).

130. And although Exxon could not have predicted this in 1994, the glacial pace of appellate review redounded to Exxon's benefit through successively restrictive punitive damage decisions from the Supreme Court. By the time the snow settled in 2008, Exxon had managed to reduce its liability for punitive damages to a 1:1 ratio. See Exxon Shipping Co. v. Baker, 128 S. Ct. 2605, $2611(2008)$.

131. See Hines, supra note 14 , at 908 . Notably, because the litigation was pursued under principles of federal maritime law, applying a body of federal common law, the Exxon Valdez precedent may have even more limited applicability to diversity-based mass torts, or other federal question cases.

132. Id.

133. Cabraser \& Nelson, supra note 4, at 428. 
certification was not vulnerable to challenges based on reverse-bifurcated trial plans such as those in Jenkins, Watson, and Hilao.

Perhaps most important, the Exxon Valdez punitive damage class certification predated Ortiz and the Second Circuit's decision in Simon II, discussed below. The Exxon Valdez certification relied heavily on a "limited punishment" theory of punitive damages, a theory which has not been validated by other federal courts. ${ }^{134}$ The Supreme Court in Ortiz did not address or endorse a limited-punishment theory for certification of a Rule 23(b)(1)(B) class. ${ }^{135}$ In Simon II, the district court also did not rely on a limited-punishment theory for certification of a Rule 23(b)(1)(B) class. ${ }^{136}$ Instead, the court invoked a "limited generosity" theory, which focuses on a defendant's assets available to pay out all claims, based on the existence of a limited fund. ${ }^{137}$ In Simon II, the district court concluded that the constitutional limits placed on the total punitive damages created a limited fund. ${ }^{138}$ On appeal, the Second Circuit hewed closely to the Ortiz requirements in repudiating the Rule 23(b)(1)(B) class certification, giving "short shrift" to the limitedpunishment theory as an independent basis for class treatment of punitive damages. ${ }^{139}$

In summary, then, proponents of the punitive damage class invoke two separate lines of authority: the Rule 23(b)(3) class illustrated by Hilao, and the Rule 23(b)(1)(B) class illustrated by Exxon Valdez. For the reasons explored above, both precedents provide tenuous support for the punitive damage class.

\section{Rule 23(b)(2) Punitive Damage Class Approved}

Commentators on the current punitive damage class debate tend to overlook the Ninth Circuit's 2007 decision in Dukes v. Wal-Mart, Inc., ${ }^{140}$ upholding certification of a Rule 23(b)(2) class action for declaratory and injunctive relief in a Title VII ${ }^{141}$ employment discrimination case, which included certification of the 23(b)(2) class for back pay and punitive damages. Significantly, the class plaintiffs in Dukes did not seek

\footnotetext{
134. See In re Simon II Litigation, 211 F.R.D. 86, 184-86 (E.D.N.Y. 2002) (discussing limited punishment theory), vacated, 407 F.3d 125 (2d Cir. 2005).

135. Id. at $183-84$.

136. Id. at $184-86$.

137. Id.

138. Id. at 185 .

139. Cabraser \& Nelson, supra note 4 , at 426.

140. Dukes II, 509 F.3d 1168 (9th Cir. 2007), rev'g Dukes I, 222 F.R.D. 137 (N.D. Cal. 2004).

141. Civil Rights Act of 1964, 42 U.S.C. $§ 2000$ e (2006).
} 
compensatory damages other than back pay. As suggested below, the Dukes punitive damage class may play a pivotal role in judicial thinking about the punitive damage class.

In Dukes, the District Court for the Northern District of California certified a Rule 23(b)(2) class and approved a two-phase trial plan. In Phase I, the plaintiffs would attempt to prove that Wal-Mart engaged in a pattern and practice of discrimination through its company-wide employment practices. ${ }^{142}$ If the plaintiffs were successful in Phase I, they would also attempt to prove an entitlement to punitive damages. ${ }^{143}$ Assuming the plaintiffs prevailed in Phase I, in Phase II the court would fashion classwide injunctive relief. ${ }^{144}$ In addition, a special master would calculate-based on an unspecified formula - a lump-sum back-pay award that Wal-Mart owed to the class. ${ }^{145}$ The court would not adjudicate the merits of any particular class members' claim. ${ }^{146}$ In addition, the district court's certification order granted notice to class members and permitted class plaintiffs to opt out of claims for punitive damages. ${ }^{147}$

On appeal, the Ninth Circuit upheld certification of the 23(b)(2) class, including the punitive damage portion of the class certification. ${ }^{148}$ Following Ninth Circuit precedent in Molski v. Gleich ${ }^{149}$ regarding Rule 23(b)(2) class certification, the appellate court found that the district court had acted within its discretion in concluding that plaintiffs' claims for punitive damages did not "predominate over their claims for injunctive and declaratory relief." 150 Moreover, the Ninth Circuit approved the district court's order of notice and opt-out rights in the (b)(2) class, finding support in precedents suggesting that an opt-out right might be appropriate where plaintiffs move to certify a class for punitive damages. ${ }^{151}$

\footnotetext{
142. See Dukes I, 222 F.R.D. at 173.

143. This inquiry would require proof that Wal-Mart's pattern and practice of discrimination "was undertaken maliciously or recklessly in the face of perceived risk that the defendant's actions would violate federal law." See id.

144. Id. at 174 .

145. Id. at 176 .

146. Id. at 187 .

147. Id. at 173 .

148. Dukes II, 509 F.3d 1168, 1193 (9th Cir. 2007).

149. 318 F.3d 937, 947-50 (9th Cir. 2003).

150. Dukes II, 509 F.3d at 1188 (citing Molski, 318 F.3d at 947-50; Robinson v. Metro-N. Commuter R.R., 267 F.3d 147, 164 (2d Cir. 2001) ("recognizing that a district court may certify a class [action] under (b)(2) if it finds in its discretion that the positive weight or value of injunctive relief is predominant even though punitive damages are claimed")).

151. See id. at 1188-89 (citing In re Monumental Life Ins. Co., 365 F.3d 408, 417 (5th Cir.
} 
The Ninth Circuit also upheld the proposed Dukes two-phase trial plan, concluding that the plan did not present manageability problems that would defeat class certification. ${ }^{152}$ The court's primary precedent for upholding the Dukes trial plan was its prior approval of the Hilao trial plan. ${ }^{153}$ The Ninth Circuit concluded:

Because we see no reason why a similar procedure to that used in Hilao could not be employed in this case, we conclude that there exists at least one method of managing this large class action that, albeit somewhat imperfect, nonetheless protects the due process rights of all involved parties.

The Dukes Rule 23(b)(2) punitive damage class represents perhaps the ultimate adventuresome expansion of the punitive damage class. First, the punitive damage class is un-tethered from Ortiz requirements because the action is not based on a limited fund, limited generosity, or limited punishment theory. Second, the Dukes class is predicated on the premise that class members may recover punitive damages in a 23(b)(2) class action, if those punitive damages may be characterized as not motivating the litigation. Third, the Dukes (b)(2) class certification authorizes the award of punitive damages unanchored to any prior finding of compensatory damages. Fourth, the Dukes (b)(2) certification permits novel notice and opt-out rights in a (b)(2) class to claimants who do not wish to claim punitive damages. And fifth, the nationwide Rule 23(b)(2) class evades scrutiny under the more stringent 23(b)(3) predominance and superiority requirements, which otherwise typically undermine the certification of multistate damage class actions.

\section{A Further Note on the Ninth Circuit's Hat Trick of Successful Rule 23 Punitive Damage Class Certifications: Some Very Mixed Metaphors}

If I were a plaintiffs' class action attorney seeking to certify a punitive damage class, I definitely would go to the Ninth Circuit. As the law now stands, the Ninth Circuit has completed a trifecta of punitive

2004); Jefferson v. Ingersoll Int'l, Inc., 195 F.3d 894, 898 (7th Cir. 1999); Ticor Title Ins. Co. v. Brown, 511 U.S. 117 (1994)).

152. Id. at 1190-91, 1193. The Ninth Circuit also rejected or deflected challenges that the proposed trial plan violated the defendant Wal-Mart's due process rights and the Rules Enabling Act, 28 U.S.C. $\$ 2072$ (b). Id.

153. Id. at 1191-92.

154. Id. at 1192-93 (citations omitted). 
damage classes, upholding such classes under Rule 23(b)(1)(B) (Exxon Valdez); Rule 23(b)(2) (Dukes v. Wal-Mart); and Rule 23(b)(3) (Hilao).

Notably, however, neither the Hilao nor the Exxon Valdez punitive damage class certifications have been subjected to Supreme Court review. The Ninth Circuit decision approving the class certification and trial plan in Hilao was never appealed to the Supreme Court. ${ }^{155}$ Hence, the Court has never reviewed the district court's Rule 23(b)(3) class certification, the Hilao reverse-trifurcated trial plan, use of statistical sampling, or the use of a special master to administer claims and awards (among many other issues). And although the Exxon Valdez punitive damage award did ultimately wend its way to the Supreme Court, the underlying class certification of the 23(b)(1)(B) punitive damage class did not.

The Dukes Rule 23(b)(2) class certification currently is pending review by the Ninth Circuit en banc. ${ }^{156}$ The Dukes litigation involves highly motivated litigants on both sides of the docket. Thus, if the Ninth Circuit en banc panel either upholds or reverses the class certification, it seems highly likely that the losing party in the class certification battle will seek Supreme Court review. ${ }^{157}$ Hence, the Dukes litigation now appears to be the most likely candidate to provide an appellate basis for Supreme Court pronouncements on the punitive damage class.

In many respects - should it wind up on the Supreme Court docketthe Dukes litigation presents an almost perfect storm of class action and punitive damage issues. The Court would be called upon to resolve an array of unsettled and conflicting lower court decisions. The Court would be called upon to resolve the Allison-Robinson-Jefferson-Molski conflict concerning the applicable standards for recovery of damages in Rule 23(b)(2) class actions. ${ }^{158}$ The Court would be called upon the review novel trial plans derived from Jenkins, Watson, and Hilao. ${ }^{159}$ The Court would be called upon the resolve the unsettled Shutts issue: whether mandatory class actions may include notice and opt-out rights. ${ }^{160}$

\footnotetext{
155. There is no record of a petition for certiorari to the Supreme Court from the Ninth Circuit's ultimate approval of the Hilao trial.

156. 556 F.3d 919 (9th Cir. 2009).

157. The defendant Wal-Mart may be more highly motivated and strategically positioned to pursue a Supreme Court appeal from the liberal Ninth Circuit to an otherwise conservative Supreme Court. Hence, an entirely rational plaintiff might determine not to bring an appeal from an order reversing class certification, to avoid setting a bad precedent for the plaintiffs' bar in future class actions.

158. See supra note 53 and accompanying text.

159. For discussion of these trial plans see supra notes 68-100 and accompanying text.

160. Phillips Petroleum Co. v. Shutts, 472 U.S. 797 (1985). See Hines, supra note 14, at 910 (noting that in Shutts, the Court "permitted personal jurisdiction over out-of-state absent class
} 
The Court would be called upon to assess the constitutional fairness of awarding punitive damages unmoored from compensatory damages.

Unfortunately, what Dukes cannot illuminate are the parameters for Rule 23(b)(1)(B) mandatory limited-fund punitive damage classes.

\section{ORTIZ, SIMON II, AND THE DEATH KNELL FOR THE PUNITIVE DAMAGE CLASS?}

This Article centers on revitalized arguments for the punitive damage class in the post-Ortiz era, which will be addressed in Part IV. However, a brief summary of the judicial holdings in Ortiz and Simon II provides context for evaluating the renewed advocacy on behalf of the punitive damage class.

In Ortiz, the United States Supreme Court invalidated a nationwide global settlement of asbestos claims that the Fifth Circuit had approved pursuant to Rule 23(b)(1)(B). ${ }^{161}$ The Ortiz settlement class primarily encompassed compensatory damages, but the settlement also included punitive damage claims. The Court noted-but did not resolve- the socalled Shutts issue inherent in mandatory, non opt-out classes: whether a federal court may exercise personal jurisdiction over absent class members with no ties to the forum, without violating constitutional due process. ${ }^{162}$

Although the Court identified several grounds for repudiating the settlement, ${ }^{163}$ the Court's core analysis focused on the requirements for establishing a legitimate Rule 23(b)(1)(B) limited-fund class. ${ }^{164}$ The Court's analysis and conclusions in large part relied on a lengthy

members because of the opportunity afforded such plaintiffs to opt-out of the class"); see also Linda S. Mullenix, Class Actions, Personal Jurisdiction, and Plaintiffs' Due Process: Implications for Mass Tort Litigation, 28 U.C. DAVIS L. REV. 871, 913-16 (1995) (stating that in Shutts, notice requirements and opt-out provisions protect absent class members); Linda S. Mullenix, Getting to Shutts, 46 U. KAN. L. REV. 727, 727 (1998). Ten years after Ortiz, the Supreme Court still has not resolved the so-called Shutts issue, that is, whether multistate, mandatory non-opt out classes violate due process in binding class members without contacts with the forum state. See Adams v. Robertson, 520 U.S. 83, 92 (1997) (dismissing writ of certiorari as improvidently granted); Ticor Title v. Brown, 511 U.S. 117, 126 (1994) (per curiam dismissal of writ of certiorari as improvidently granted).

161. Ortiz v. Fibreboard Corp., 527 U.S. 815, 864 (1999). See generally Hines, supra note 14, at 909-21 (describing the Ortiz decision); Nagy, supra note 14, at 603-06 (same).

162. Ortiz, 527 U.S. at $847-48$. See Shutts, 472 U.S. at 812 n.3.

163. Similar to its reasoning in Amchem, decided two years earlier, the Court held that the Ortiz class failed for a lack of adequacy of representation and typicality. See Amchem Prods. Inc. v. Windsor, 521 U.S. 591, 594 (1997); Ortiz, 527 U.S. at 831-32.

164. Ortiz, 527 U.S. at $838-40$. 
historical exegesis of the limited-fund class action. ${ }^{165}$ Reviewing this history, the Court set forth three criteria for certification of a limited-fund class, requiring proof of: (1) the existence of an actual limited or insufficient fund, (2) use of the entire inadequate fund to pay all the claims in the class action, and (3) equitable treatment of all class claimants. ${ }^{166}$

The Court concluded that the Ortiz settlement failed all three requirements. First, there was no evidence of the existence of a truly limited fund because the settling parties had agreed to this by stipulation. ${ }^{167}$ In order to certify a limited-fund class action, a court must evaluate the number of claims against the fund as well as the defendant's total assets. ${ }^{168}$ The Supreme Court held that parties must submit evidence that enables a court to "ascertain the limit and sufficiency of the fund, with support in findings of fact."169 The Court also held that the Ortiz settlement failed the second requirement because, under the terms of the settlement, the defendant Fibreboard was able to continue its operations and retain almost all its net worth. ${ }^{170}$ Finally, the Court held that the Ortiz settlement failed the third requirement of equitable distribution among class members because of a lack of inclusiveness in the class, and fairness of distributions to those within the class. ${ }^{171}$

The Ortiz decision, however, essentially did not address a Rule 23(b)(1)(B) punitive damage class certification because punitive damage claims were not at the heart of the Ortiz settlement. As the ensuing decade has demonstrated, the Ortiz Court's demanding requirements for certification of a Rule 23(b)(1)(B) limited fund have frustrated almost all attempts to certify a limited-fund class action. Similar to the pre-Ortiz era, proponents of limited-fund class actions continue to have difficulties proving up the existence of a limited fund pursuant to post-Ortiz standards. In addition, proponents of limited-fund class certification after Ortiz must satisfy two additional requirements. Hence, judicial approval of Rule 23(b)(1)(B) settlement classes have been

165. Id. at $833-37$.

166. Id. at $838-40$.

167. Id. at 848-49.

168. Id. at 850 .

169. Id. at 849 .

170. Id. at 859-60.

171. Id. at 854-55. See also Hines, supra note 14, at 911-12 (discussing problems of Ortiz class under-inclusiveness and failure of the settlement proponents to provide structural assurances of due process fairness, as required by Amchem, such as subclassing or independent counsel); Nagy, supra note 14, at 606 (describing reasons for failure to satisfy the third equitable distribution requirement). 
extraordinarily rare. ${ }^{172}$ Moreover, the prospect of certifying a standalone punitive damage class after Ortiz (as in Dukes v. Wal-Mart) presents even more challenging due process obstacles. ${ }^{173}$

The core Ortiz requirement for proof of a limited fund presents the chief reason for failure of post-Ortiz limited-fund class actions. Hence, the Supreme Court's articulation of a constitutional punitive damage jurisprudence breathed new life-theoretically-into the possibility of the limited-fund class action; the Court's line of cases provided a new way of thinking about what constitutes a limited fund. Hence, in the Simon II tobacco litigation, class counsel seized this opportunity and urged the novel theory that the constitutional cap on punitive damages, suggested by the Supreme Court, created the limited fund. ${ }^{174}$ Judge Weinstein agreed, and on this basis found a limited fund and certified a Rule 23(b)(1)(B) punitive damage class action. ${ }^{175}$

The Second Circuit vacated and remanded the class certification. ${ }^{176}$ The Second Circuit recognized that the Simon II class certification presented the court with a case of first impression: certification of a mandatory, non opt-out stand-alone punitive damage class based on a limited-punishment theory. ${ }^{177}$ After canvassing the theories underlying both the limited-punishment and limited-generosity classes, the Second Circuit relied on neither construct to evaluate the certification of the Simon II punitive damage class. Instead, the court analyzed the Simon II class certification pursuant to the stringent Ortiz requirements for certification of a Rule 23(b)(1)(B) class. ${ }^{178}$

The Second Circuit held that the first fundamental requisite for limited-fund treatment under Ortiz was lacking, because there was no "evidence on which the district court may ascertain the limit and insufficiency of the limited fund." 179 Addressing the proposed fund,

172. See, e.g., In re Orthopedic Bone Screw Prods. Liab. Litig., 350 F.3d 360, 363 (3d Cir. 1999) (describing 23(b)(1)(B) class settlement as "final and unappealable").

173. See Hines, supra note 14, at 912 n.126.

174. In re Simon II Litig., 211 F.R.D. 86, 184-86 (E.D.N.Y. 2002), vacated 407 F.3d 125 (2d Cir. 2005).

175. Id. at 185 ("Rather, it is the Constitution through limits placed in total punitive damages which creates the limited fund.").

176. In re Simon II Litig., 407 F.3d 125, 132, 134-36 (2d Cir. 2005). The Second Circuit reviewed, at length, the district court's reliance on emerging scholarship endorsing the limitedpunishment theory for certifying a punitive damage class pursuant to the Supreme Court's punitive damage jurisprudence. Id.

177. Id. at 132 .

178. In so doing, the Second Circuit recognized that Ortiz "considered a set of circumstances quite unlike those in the instant case." Id. at 136.

179. Id. at 138 . 
based on a constitutional cap on punitive damages, the Second Circuit concluded:

The proposed fund in this case, the constitutional "cap" on punitive damages for the given class's claims, is a theoretical one, unlike those in the cases cited in Ortiz, where the fund was either an existing res or the total of defendants' assets available to satisfy claims. The fund here is - in essence - postulated, and for that reason it is not susceptible to proof, definition, or even estimation, by any precise figure. It is therefore fundamentally unlike the classic limited funds of the historical antecedents of Rule $23 .{ }^{180}$

The court further indicated that not only was the upper limit of the fund difficult to ascertain, but the record in the case did not provide any evidence that any given number of punitive damage awards to individual claimants would be "excessive, either individually or in the aggregate, and thus overwhelm the available fund." 181 Thus, without any evidence indicating the upper limit or insufficiency of the fund, class plaintiffs could not demonstrate that they would be prejudiced if left alone to pursue separate actions. ${ }^{182}$

Having concluded that the Simon II class certification failed under Ortiz requirements, the Second Circuit additionally noted that the scope of the district court's order, covering all punitive damage claims nationwide, violated Supreme Court guidelines in State Farm v. Campbell. ${ }^{183}$ The district court's order had suggested that the Simon II class action could extend to "include punitive damages due to outrageous conduct by defendants towards non-class members."184 The Second Circuit disagreed, holding that "State Farm made clear that conduct relevant to the reprehensibility analysis must have a nexus to the specific harm suffered by the plaintiff, and that it could not be independent of or dissimilar to the conduct that harms the plaintiff." 185 Therefore, harmful behavior that was not "correlatable" with class members and the harm or potential harm to them would be precluded under State Farm."186

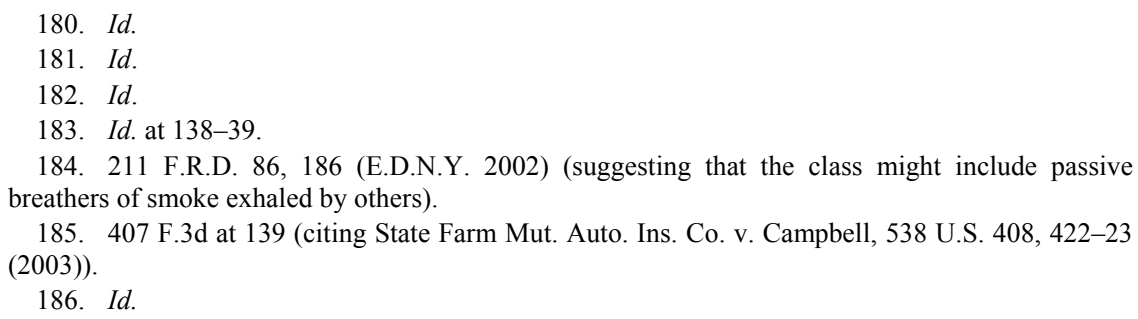


Finally, it is worth noting that the Second Circuit, in adopting the Ortiz traditional limited-fund model as its analytical construct, also endorsed the Supreme Court's cautionary rhetoric eschewing adventuresome applications of Rule 23 "in ways that would have been beyond the contemplation of the drafters of the Advisory Committee Notes." 187 Because the Second Circuit concluded that the Simon II class failed to satisfy the Ortiz requirements for ascertaining a limited fund, the court did not address the additional appellate issues involved in the Simon II trial plan. ${ }^{188}$

The Second Circuit's decision in Simon II was the first direct application of Ortiz principles - coupled with the Supreme Court's punitive damage jurisprudence - to a stand-alone punitive damage class. The Second Circuit married the punitive damage class to the traditional Ortiz model rather than adopting a limited-punishment or limitedgenerosity theory in support of the punitive damage class. In hewing closely to the traditional Ortiz mode of analysis, the Simon II decision seemed to have sounded the death knell for punitive damage classes.

The Second Circuit vacated the Simon II punitive damage class certification in 2005. ${ }^{189}$ Two years later, in Philip Morris USA v. Williams, the Supreme Court handed down yet another decision discussing the constitutional limitations on jury instructions relating to punitive damages. ${ }^{190}$ In Williams, the Supreme Court held that the due process clause prohibits a jury from basing a punitive damage award in part on a desire to punish a defendant for injuries to people who were not parties to the action. ${ }^{191}$ However, the Court indicated that a jury might properly consider harm to others when evaluating the degree of a defendant's reprehensibility. ${ }^{192}$

187. Id. at 137 (citing Ortiz v. Fibreboard Corp., 527 U.S. 815, 842 (1999)). The Second Circuit, mindful that the Supreme Court had "counseled 'against leniency in recognizing mandatory limited fund actions in circumstances markedly different from the traditional paradigm," held "that the first fundamental requisite for limited fund treatment is lacking here."). Id. at 137-38 (quoting Ortiz, 527 U.S. at 864).

188. Id. at 139-40 (declining to address whether the Simon II class violated the Rules Enabling Act, whether the court's trial plan violated the Seventh Amendment right to trial by jury, whether it was impermissible for the court to employ a "fraud on the market" presumption for proof, whether the use of statistical sampling violated due process, and whether the district could resolve class claims by applying one state's law).

189. Id. at 140 .

190. 127 S. Ct. 1057 (2007).

191. Id. at 1063.

192. Id. at 1063-64. Stated somewhat differently, a jury could only consider harm to the named plaintiff when calculating the amount of punitive damages owed to the particular plaintiff and could not base that calculation on the jury's understanding of broader harm to other nonparties who were not before the court in a particular case. 
For some commentators, the Court's pronouncements in Williams represented the ultimate nail in the coffin for the punitive damage class. ${ }^{193}$ The Court's requirements for particularized punitive damage awards tied findings of harm to particular plaintiffs and doomed prospects of implementing punitive damage classes in the future:

By stating that due process requires punitive damages to be based on harm to particular plaintiffs whose evidence is before the jury-neither the multiplier nor lump-sum approach allows the defendant to offer every available defense, nor provide sufficient information on the extent of harm to those other than the class representatives, such that the punitive damage award can be said to bear a "reasonable relationship" to compensatory damages. ${ }^{194}$

Commentators also construed the Williams decision as undermining, if not invalidating, novel Jenkins-style reverse-bifurcated trial plans that supported certification of punitive damage classes in the past. ${ }^{195}$ Thus, if punitive damages may only be awarded based on prior findings of wrongdoing and compensatory damages, then, in theory, reversebifurcated trial plans should not survive Williams.

In spite of a growing consensus that Ortiz, Simon II, and Williams have doomed the punitive damage class, pronouncements of the death of the punitive damage class may once again be premature.

\section{The ReVitalized ARguments For the Punitive Damage Class AFTER ORTIZ}

\section{A. The Revitalized Argument for a Rule 23(b)(1)(B) Punitive Damage Class}

As indicated above, although many commentators have viewed the Court's decision in Williams as undermining the possibility of the punitive damage class, proponents find in Williams an arguable basis for the punitive damage class, especially when it is wedded to the classic

193. See, e.g., Sheila B. Scheuerman, Two Worlds Collide: How the Supreme Court's Recent Punitive Damages Decisions Affect Class Actions, 60 BAYLOR L. REV. 880, 884 (2008) (arguing that after the Supreme Court's decision in Williams, punitive damages cannot be pursued as a classwide remedy); Stier, supra note 63, at 433 (arguing that Supreme Court's decision in Williams hastens the continuing demise of the mass-tort punitive damage class action with individualized issues such as causation, damages, and choice of law).

194. Stier, supra note 63, at 445-46.

195. See id.; see also Schwartz \& Appel, supra note 63, at 375. 
deterrent function of punitive damages. ${ }^{196}$ These commentators advocate certification of a traditional punitive damage class under Rule 23(b)(1)(B). In addition, these proponents find further support for the punitive damage class in Williams's holding that a court can and should consider harm to others when evaluating the degree of reprehensibility of the defendant's conduct. ${ }^{197}$

Still other proponents acknowledge the obstacles to the punitive damage class raised by Ortiz, Simon II, and Williams, and the consequent difficulties of securing approval for a Rule 23(b)(1)(B) limited-fund class since these decisions. ${ }^{198}$ Instead, these advocates propose that the Supreme Court salvage the punitive damage class by articulating an exception to the historical limited-fund models endorsed in Ortiz. ${ }^{199}$

The advocates for the traditional Rule 23(b)(1)(B) punitive damage class, then, would stand the Williams decision on its head and seize upon the Williams Court's focus on harm to the individual plaintiff as validating the punitive damage class. In this reading, attention is deflected away from the limited-punishment theory, which concerns excessive punishment on the defendant as a consequence of multiple punitive damage awards.

The "focus-on-the-plaintiff" theory inspired by Williams leads to a bootstrap argument in support of the punitive damage class. Pursuant to this argument, if the court's focus is on harm to the individual plaintiff, then an excellent solution is to join lots of individual plaintiffs together in one action. Thus, leading proponents of the punitive damage class have suggested: "If the Court's focus, after Philip Morris [v. Williams], must remain on the harm to the individual plaintiff... then the procedural solution to preserving punitive damages' classical deterrent function may lie in the aggregation of plaintiffs, via class action or other joinder mechanisms."200 These advocates suggest:

The obvious solution to the "punishment for harm to plaintiffs only" dictate of Philip Morris [v. Williams] is to bring more plaintiffs before the court, not only to assure that an adequate level of deterrence is

196. See Cabraser \& Nelson, supra note 4, at 412, 421-29.

197. This reprehensibility requirement derived from the Court's prior holdings in $B M W$ of North America v. Gore, 517 U.S. 559 (1996), and State Farm Mutual Automobile Insurance Co. v. Campbell, 538 U.S. 408 (2003). See Elizabeth J. Cabraser \& Michael G. Nast, Commentary, A Plaintiff's Perspective on the Effect of State Farm v. Campbell on Punitive Damages in Mass Tort, 3 MEALEY's Litig. ReP.: Class ACTIONS, June 19, 2003, at 1 (discussing how reprehensibility factor articulated in State Farm supported punitive damage class).

198. Nagy, supra note 14, at 624 .

199. Id.

200. Cabraser \& Nelson, supra note 4, at 412. 
approached, but to level the playing field in such a societally essential litigation arena by enabling plaintiffs to obtain at least some of the economies of scale of aggregate prosecution, and to lessen the odds that an egregiously reprehensible defendant will elude full accountability for large-scale misconduct. If punitive damages are to stand as a civil penalty for the transgression of the social compact they must continue to sting, in order to perform their deterrent and exemplary functions. ${ }^{201}$

The "more-plaintiffs-are-better" argument, based on the Court's Williams decision, seems a non sequitur. It appears quite a stretch to suggest that the Court's focus on proving up harm to the individual plaintiff in Williams supports expansion of the Court's holdings to embrace a punitive damage class.

Proponents of the punitive damage class also argue that the Court's continued endorsement of the BMW-State Farm reprehensibility factor supports classwide treatment of punitive damages. ${ }^{202}$ In this view, if harm to others is a key factor in determining reprehensibility - and the degree of reprehensibility is a key determinant in a jury's decision to award punitive damages - then harm to others will always be an integral part of any punitive damages case. In this view, the Court's decision in State Farm v. Campbell suggests that all persons claiming harm from a reprehensible course of conduct should be included in a single proceeding to determine punitive damages under appropriate state law. ${ }^{203}$ The class action, then, is the ideal procedural vehicle for assessing such harm to others.

However, the Court's continued endorsement of the reprehensibility factor in State Farm and Williams seems too slim a reed upon which to bootstrap justification for the punitive damage class. The Court's punitive damage pronouncements in BMW, State Farm, and Williams all occurred in lawsuits brought by individual plaintiffs. None of those cases involved a class action for punitive damages. Thus, in assessing liability for punitive damages, the reprehensibility factor enables a jury to consider evidence relating to nonparties to determine the level of reprehensibility (if any) of a defendant's conduct in an individual lawsuit.

201. Id. at 421 .

202. See id. at $413-14$.

203. Id. at 429. Cabraser and Nelson concede, however, that if a classwide treatment of punitive damages is ever to survive appellate scrutiny, such a class would have to be based on a trial plan that resembled a traditional trial chronology of liability determination, compensatory damage determination, followed by punitive damage consideration. See id. at 428-29. 
But the reprehensibility factor is just that: a single factor in a complex jury determination in an individual lawsuit. The fact that the Court's decisions in State Farm and Williams permit juries to reference harm to others in assessing reprehensibility has nothing to do with whether a jury may consider harm to nonparties in calculating and determining individual punitive damage awards. The Court clearly has indicated that this is constitutionally impermissible. Hence, it remains entirely uncertain (if not dubious) whether the Supreme Court intended its endorsement of the reprehensibility factor, alone, to support endorsement of a classwide punitive damage procedural vehicle for the calculation and award of punitive damages.

In a class action, individual claims are not "joined," and the class action mechanism is not actually a joinder device. Class action litigation is representational litigation, and, therefore, class members are not parties to the litigation in any formal sense, or before the court or the jury. Absent class members are precisely that: absent. Hence, the BMW-State Farm-Williams stricture against calculating a punitive damage award based on nonparties to the litigation is equally applicable to the class action context. The mere aggregation of absent class members in a representational litigation does not actually bring these individual claims before the court.

Other proponents of the punitive damage class concede that it is hard to imagine that the current Supreme Court would not consider a Rule 23(b)(1)(B) mandatory punitive damage class "adventurous" after Ortiz. ${ }^{204}$ A commentator further concedes that, while Ortiz did not directly address the question of the punitive damage class certified under Rule 23(b)(1)(B), "the Court's language impliedly disallows a departure from the rule's traditional application." 205 Hence, class counsel seeking to certify a Rule 23(b)(1)(B) punitive damage class in the post-Ortiz era face considerable obstacles to proving up the requirements of a traditional limited-fund action. ${ }^{206}$

Acknowledging the severe limitations imposed by Ortiz, ${ }^{207}$ proponents nonetheless suggest that "utility and fairness suggest a need for the availability of such certification." 208 Based completely on public policy arguments, these advocates therefore suggest that the Supreme

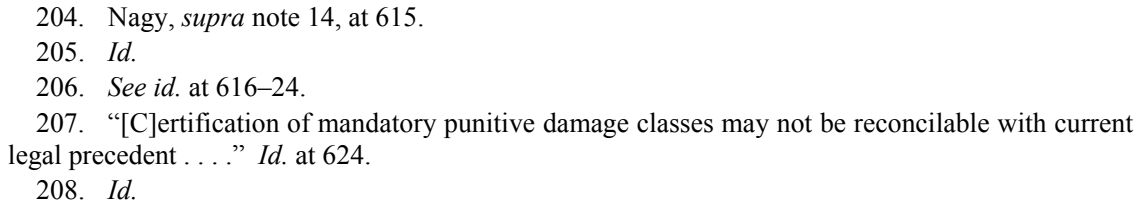


Court revisit the issue of limited-fund class actions and make an exception from the traditional mandate in Ortiz when applying Rule 23(b)(1)(B) to punitive damage classes. ${ }^{209}$ The public-policy rationales advanced in support of a punitive damage class exception are grounded in (1) fairness to plaintiffs (windfall awards violate distributive justice), ${ }^{210}$ (2) benefits to defendants (the limited generosity and limited punishment theories), ${ }^{211}$ and (3) efficiencies in resolving mass-tort litigation. $^{212}$

That the Supreme Court would depart from a rules-based analysis of the limited-fund class action to support an exceptional departure for the punitive damage class, based largely on policy rationales, seems improbable. It should be remembered that the considerable policy rationales advanced in support of the global asbestos settlements in both Amchem and Ortiz failed to convince at least six Justices to resolve the mass-tort litigation crisis in the federal courts. ${ }^{213}$ Finally, even assuming that the Supreme Court granted review of a Rule 23(b)(1)(B) punitive damage certification, multistate or nationwide mandatory class actions would still be vulnerable to Shutts challenges and choice-of-law issues. ${ }^{214}$

\section{B. The Revitalized Argument for a Rule 23(b)(3) Punitive Damage Class}

While some commentators have attempted to resuscitate the Rule 23(b)(1)(B) punitive damage class, others have recognized that the Ortiz Court's view "of a true limited fund have made the utility of Rule 23(b)(1)(B) for obtaining class certification of a tort suit for damages very difficult." 215 These realists, then, have abandoned hope for the

\footnotetext{
209. Id.

It seems that the easiest way to facilitate a needed change in the law would be for the Supreme Court to grant certiorari on this issue. To achieve fairness and efficiency in mass tort litigation in the future, the Supreme Court should rethink Ortiz's limitations on certification under 23(b)(1)(B). By making an exception to the traditional application of the rule for mandatory punitive damage classes, courts will be able to grant certification on a limited fund theory - even when the fund is only theoretically limited by the legal limits on punitive damage liability.

Id. at 629 (citation omitted).

210. Id. at 624-26. Cf. Mesulam, supra note 14, at 1139-40 (debunking the "plaintiff-centric" myth of punitive damages).

211. Nagy, supra note 14, at 626-27.

212. Id. at 628 .

213. Ortiz was a 7-2 decision and Amchem was a 6-2 decision with Justice O'Connor taking no part in the consideration of that case.

214. Nagy, supra note 14, at 629 n.218.

215. Underwood, supra note 1, at 783.
} 
23(b)(1)(B) class, and instead have surprisingly shifted aspirations for the punitive damage class back to the 23(b)(3) arena. ${ }^{216}$ Thus, one advocate has suggested that the critical commentary suggesting that State Farm and Williams are hostile to the punitive damage class, "is certainly overstated if not misguided." 17 Viewing the Court's punitive damage jurisprudence, this advocate concludes that, "[p]roperly understood, these authorities actually create pro-certification arguments that suggest a possible path for resurgence of the 23(b)(3) class action. The Supreme Court may have inadvertently just breathed new life into the punitive damage class action." 218

The gist of the argument is that a Rule 23(b)(3) class action solves the paradox raised by the Court's mandate in Williams. Thus, in ascertaining the degree of a defendant's reprehensibility, the focus need not be limited to a particular claimant's harm. ${ }^{219}$ However, a jury may consider harm to third parties only for the purpose of reprehensibility, not for the purpose of punishing the tortfeasor. ${ }^{220}$ Resort to class certification in mass-tort cases resolves this paradox. ${ }^{221}$ Victims of the tortfeasor's misconduct are thereby converted from strangers into class members. ${ }^{222}$ The Supreme Court has determined that class members in a certified case are hardly strangers to the litigation and that the Due Process Clause protects their interests in class action proceedings. ${ }^{223}$

Additionally, the issue of punitive damage liability for a mass tortfeasor is one shared in common by all claimants, supporting findings of commonality under Rule 23(a), and predominance under 23(b)(3). ${ }^{224}$ And certification of a punitive damage class is superior to traditional one-on-one litigation when viewed through the prism of the multiplepunishment concern. ${ }^{225}$

Advocates of the Rule 23(b)(3) punitive damage class further suggest that, as a matter of trial procedure, the Court's punitive damage jurisprudence creates no barriers to trial courts bifurcating the punitive damage issue and allowing a jury in the first trial phase to enter a

\footnotetext{
216. Id. at $796-806$.

217. Id. at 796 .

218. Id. at 797 .

219. Id. at 798 .

220. Id. at 801 .

221. Id. at 802 .

222. Id.

223. Id. at 797 .

224. Id. at 798-99.

225. Id. at 800 .
} 
multiplier of punitive-to-actual damages. ${ }^{226}$ In subsequent individual trials, juries could rule on the merits of individual liability matters and determine each class member's actual damages, thus permitting the trial court-upon engaging in State Farm-mandated analysis-to enter final judgment using the original jury's punitive damage multiplier. ${ }^{227}$

This brief on behalf of a revitalized Rule 23(b)(3) punitive damage class is fraught with conceptual and practical difficulties. As indicated above, the class action procedural mechanism is not a surrogate device for converting strangers to the litigation into parties. If class members are properly characterized as nonparties, then the Williams stricture prohibiting an award of punitive damages based on reference to nonparties carries equal force in the class action context. The 23(b)(3) class action does not, as suggested by its advocates, solve the so-called Williams paradox.

Advocacy on behalf of the Rule 23(b)(3) punitive damage class, as described above, rests on approval of Jenkins-style reverse-bifurcated trial plans, which have never been approved by the Supreme Court. Even leading plaintiffs' class counsel now suggest that the Court's evolving punitive damage jurisprudence probably does not support such reverse-bifurcated trial plans because punitive damages must be anchored to prior findings of compensatory damages. ${ }^{228}$ In addition, the complicated description of possible multiphase classwide and individual trials for compensatory and punitive damage awards undercuts arguments based in efficiency, economy, and superiority. ${ }^{229}$

Moreover, recourse to the 23(b)(3) class category for certification of a punitive damage class raises the specter of other complicating problems not addressed by its proponents, such as choice-of-law issues in multistate and nationwide mass torts. More than twenty-five years ago, federal courts suggested that nationwide punitive damage classes were not viable under 23(b)(3) because of applicable-law problems. ${ }^{230}$ This barrier to the 23(b)(3) punitive damages class action has not changed in the intervening years since the Dalkon Shield litigation.

226. Id. at 804

227. Id.

228. See Cabraser \& Nelson, supra note 4, at 428-29 ("[A] trial plan that most resembles a traditional trial chronology of liability determination, compensatory damage determination, and then punitive damage consideration, is most likely to withstand appellate scrutiny.").

229. Bifurcated trial plans also raise serious constitutional issues under the Seventh Amendment's Reexamination Clause. See Castano v. Am. Tobacco Co., 84 F.3d 734, 750-51 (5th Cir. 1996); In re Rhone-Poulenc Rorer, Inc., 51 F.3d 1293, 1302-03 (7th Cir. 1995).

230. See, e.g., Dalkon Shield, supra note 3, 693 F.2d 847. 
Additionally, Rule 23(b)(3) class actions require notice and the right to opt out of the class. It is perhaps worth noting that an opt-out punitive damage class seems to undermine the interests of plaintiffs, defendants, and the judicial system. A 23(b)(3) opt-out punitive damage class is inconsistent with the goal of avoiding punitive damage overkill. Thus, a defendant in a 23(b)(3) opt-out punitive damage class gains little benefit from aggregating some of its punitive damage exposure, and instead runs the risk of individual litigants seeking multiple successive punitive damage awards in individual litigation. This seems a likely reason why the Exxon Corporation sought certification of a 23(b)(1)(B) non-opt-out punitive damage class in the Exxon Valdez litigation.

Conversely, a Rule 23(b)(3) opt-out class does not serve the interests of class plaintiffs. Class members who opt out of a punitive damage class are then free to litigate their compensatory and punitive damage claims in individual litigation. However, when faced with a pending parallel class action, this scenario might induce a race to the courthouse to accomplish punitive damage recovery. The Third Circuit recognized the possibility of just such a race to the courthouse in the School Asbestos Litigation. ${ }^{231}$

\section{The Revitalized Argument for Punitive Damage Class Based on CAFA}

A third, and perhaps the most inventive, argument on behalf of the punitive damage class is anchored in the Class Action Fairness Act of 2005 (CAFA) ${ }^{232}$ As is well-known, CAFA created new original federal diversity jurisdiction for class actions, as well as a new removal provision for removing state class actions into federal court. In addition, CAFA recognized the existence of "mass action" cases that also were subject to the statute's removal provisions. ${ }^{233}$

Proponents of the punitive damage class now suggest that CAFA's provision for federal adjudication of "mass action" cases provides an effective vehicle for quasi-classwide adjudication of punitive damages, without the burdens of formal class certification. In this sense, the CAFA mass-action provision presents an even better procedural opportunity for seeking aggregate punitive damages (if you are a

231. See supra notes 44-47 and accompanying text.

232. Pub. L. 109-2, 119 Stat. 4 (codified as amended at 28 U.S.C. $\S 1332(d)$ and 28 U.S.C. $\S$ 1453 (Supp. 2007))

233. See 28 U.S.C. $\S 1332(d)(11)$ (stating a "mass action shall be deemed to be a class action removable" under $(\mathrm{d})(2)-(10)$ if the requirements within those provisions are met). 
plaintiff). Thus, the advocates for this view argue that CAFA's embrace of mass actions

present[s] an intriguing format for the cost-effective determination of punitive damages liability and quantum to large numbers of plaintiffs in a single proceeding. The class economies of scale are present, without the cost, delay, and risk of obtaining formal certification under Rule 23. Plaintiffs may be grouped in multiple mass actions, by type of claim, severity of injury, and other factors that maximize factual and legal commonality. This facilitates a single jury's evaluation of reprehensibility of the defendant's conduct toward the group before the court, and the resulting harm to that group. Thus, mass actions more nearly achieve the goal of deterrence and punishment than could scattered or sporadic single-plaintiff trials. ${ }^{234}$

The CAFA mass-action theory is nothing if not creative. Since its enactment, CAFA has come to be freighted with all sorts of proposed uses never intended by its authors. One need not tarry over the CAFA argument, however. There is nothing in the legislative history of CAFA to suggest that Congress, in referencing mass actions, intended to create a new aggregate litigation mechanism that would enable federal courts to adjudicate aggregate punitive damages, or to avoid class certification requirements. The CAFA mass-action provision was included in the legislation to address a specific gap in the CAFA's removal provisions.

CAFA was intended to address abuses by state courts in handling state-based class actions. To address these abuses, it is widely acknowledged that the primary purpose of CAFA was to provide a new removal statute to permit removal of state class actions into federal court. $^{235}$ Forty-eight of the fifty states have class action rules or statutes $;{ }^{236}$ Mississippi and Virginia do not. ${ }^{237}$ However, procedural rules in both Mississippi and Virginia allow for the joinder of large numbers of individual claims. CAFA's removal provisions applied only to state class actions, and in absence of the mass-action provision, would not have reached aggregate litigation in those two states. Hence, the mass-

234. See Cabraser \& Nelson, supra note 4 , at 430.

235. See H. Hunter Twiford, Anthony Rollo \& John T. Rouse, CAFA Enunciates a New Burden of Proof Standard for Federal Jurisdiction, CONSUMER FIn. SERVICES L. REP. (LRP Publications, West Palm Beach, Fla.) Aug. 9, 2006 (stating that Congress sought to "increase access to the federal courts for interstate class actions" with the adoption of CAFA).

236. See Linda S. Mullenix, State Class Actions: Practice and Procedure xi (2007) (explaining that many states amended their approach to class action suits by enacting rules similar to the federal rules after the advisory committee amended Federal Rule 23).

237. See id. at 26,011 (Miss. § 103 (A)), 48,011 (Va. § 1.01) (stating that Mississippi and Virginia both have no civil procedure rule governing class action lawsuits). 
action provision was included in CAFA to permit removal of aggregate litigation cases from Mississippi and Virginia state courts, the same as class actions in other states.

CAFA's mass-action provisions were not intended to create new forms of action that allow litigants to circumvent class certification requirements. $^{238}$ It no doubt would come as a great surprise to the legislation's sponsors to discover that CAFA's mass-action provisions were now interpreted to provide a basis for aggregate resolution of punitive damages, outside the class action context.

\section{CONCLUSION}

As suggested at the outset of this Article, the concept of the punitive damage class action seems to enjoy nine lives: no matter how many times courts seem to repudiate the idea, or lay it to rest, the punitive damage class seems to spring back to life with renewed fervor. Notwithstanding its widely perceived death-knell in Ortiz and Simon II, the proponents of the punitive damage class nonetheless forge onwards with innovative theories in support of the punitive damage class. Indeed, in sometimes hyperbolic rhetoric, proponents of the punitive damage class hail this concept as the twenty-first century salvation for mass tortlitigation. $^{239}$

To date, very few punitive damage class actions have survived appellate scrutiny, and no punitive damage class has ever been subject to Supreme Court review. However, there is merit to the academic contention that the Supreme Court's punitive damage jurisprudence either is on a convergence or collision course with Rule 23. Hence, the Supreme Court will be the ultimate arbiter of whether the punitive damage class is a viable mechanism, consistent with the Court's constitutional punitive damage jurisprudence.

Three scenarios, at least, suggest such possible review. First, federal court approval or disapproval of a Rule 23(b)(1)(B) limited fund under

238. There is some merit to the point, however, that the Williams mandates would have more force in a simple joinder case where individual claims might be separately tried.

239. See Underwood, supra note 1, at 807 ("On the other hand, many commentators and courts are myopic in their failure to recognize in these decisions their demonstration of the superiority of the class action joinder device in Rule 23(b)(3) cases-a consequence that argues strongly for the enhanced utility of class actions in punitive damage cases. In addition to providing systemic relief, the class device offers the best hope for a solution to the redundant punishment problem that was itself the original impetus for the Court's initial foray into substantive due process for punitive damages and also renders moot the paradox of the strained Philip Morris procedural due process holding. Properly viewed, the Supreme Court has offered a route back toward the viable use of the class action device for resolving mass punitive damage disputes."). 
Ortiz requirements would compel consideration of whether the Court ought to craft an exception to Ortiz, based on a limited-punishment or limited-generosity concept. The Second Circuit's rejection of the 23(b)(1)(B) punitive damage class in Simon II, and the Ninth Circuit's approval of the 23(b)(1)(B) class in Exxon Valdez, provided platforms for such review. However, those certifications were not appealed to the Court for review. Therefore, resolution of a possible Ortiz exception for punitive damage classes awaits further development in the lower federal courts.

A second scenario that would inspire Supreme Court pronouncements regarding the punitive damage class would arise if lower federal courts were to embark on renewed certification of punitive damage classes under Rule 23(b)(3), marrying the (b)(3) class to the Court's punitive damage jurisprudence. Such punitive damage classes necessarily would implicate utilization of the historical Jenkins-style reverse-bifurcated trial plans, as the twenty-first century advocates for the punitive damage class suggest. This prospect, then, would invite the Supreme Court to evaluate Jenkins-style reverse-bifurcated trial plans, on which the Court has not ruled to date.

Rule 23(b)(3) punitive damage classes, however, may arise in factually distinct contexts that would further muddy evaluation of such class certifications. Hence, both Jenkins and Watkins involved narrowly circumscribed classes that did not entail multistate applicable-law complications. In contrast, sprawling nationwide mass torts certified under 23(b)(3) most likely would entail additional certification minefields - the requirements for predominance, superiority, and manageability.

A third scenario that might invite Supreme Court review would be appellate approval or disapproval of a Rule 23(b)(2) punitive damage class. As indicated above, the Dukes v. Wal-Mart litigation pending in the Ninth Circuit appears to be the most likely candidate to inspire such Supreme Court review. This prospect would involve the Court not only in its punitive damage jurisprudence, but would lure the Court into resolving conflicting circuit court decisions on damages recovery in a 
23(b)(2) class, ${ }^{240}$ as well as other long-simmering class action issues, such as notice and opt-out rights in mandatory classes.

This much is certain: proponents of the punitive damage class - ever inventive and ever hopeful-will continue to pursue certification of such classes under all provisions of Rule 23. The issue of the legitimacy of the punitive damage class is destined to be raised in a piecemeal fashion pursuant to every conceivable class certification category. And consequently, it seems likely that the Court will be unable to articulate a unified theory of the punitive damage class that will apply to all cases, given the array of possible means for structuring the punitive damage class (as well as the array of underlying factual circumstances giving rise to such litigation). Until the Court cycles through all possible variations of punitive damage class certification, it is difficult to envision a unified theory of the punitive damage class.

Finally, a cautionary note. If Ortiz is any guidance, the signal message from the Court is circumspection toward adventuresome use of Rule 23. ${ }^{241}$ If a conservative Court in Ortiz repudiated innovative efforts to solve the "elephantine" crisis of asbestos litigation in the courts through a settlement class, then it is difficult to contemplate an even more conservative Court now creating a new vehicle for a punitive damage litigation class pursuant to the $23(\mathrm{~b})(1)(\mathrm{B})$ class category. The same admonition against adventuresome applications of Rule 23 would seem to apply with equal force to the novel Jenkins-style trial plans of the 1990s. Finally, shoe-horning the punitive damage class into the 23(b)(2) category would require this conservative Court to endorse the liberal, innovative constructions of the 23(b)(2) category from the Second and Ninth Circuits.

I don't think so.

240. A potential fourth opportunity for considering the punitive damage class certification could arise pursuant to a class certified under Rule 23(c)(4)(a), the so-called "limited-issues" class. Hence, a district court conceivably could certify a punitive damage class for a determination of punitive damage liability or a punitive damage multiplier. The Supreme Court has not, to date, decided a case construing the applicability of a limited-issues class. The problem of the limited-issues class is itself a contested class action issue among the federal courts.

241. See In re Simon II, 407 F.3d 125, 137-38 (2d Cir. 2005) (adopting the Supreme Court's cautionary approach to adventuresome uses of Rule 23, especially in the limited-fund class action, in repudiating the district court's certification of a stand-alone mandatory punitive damage class). 